\title{
Differential Accumulation of Misfolded Prion Strains in Natural Hosts of Prion Diseases
}

\author{
Zoe J. Lambert ${ }^{1,2,3} \mathbb{C}^{-}$, Justin J. Greenlee ${ }^{2}$, Eric D. Cassmann ${ }^{2}\left(\mathbb{D}\right.$ and M. Heather West Greenlee ${ }^{1, *(\mathbb{D})}$ \\ 1 Department of Biomedical Sciences, Iowa State University College of Veterinary Medicine, 1800 Christensen, \\ Ames, IA 50011, USA; zlambert@iastate.edu \\ 2 Virus and Prion Research Unit, National Animal Disease Center, Agricultural Research Service, United States \\ Department of Agriculture, 1920 Dayton Ave., Ames, IA 50010, USA; justin.greenlee@ars.usda.gov (J.J.G.); \\ eric.cassmann@ars.usda.gov (E.D.C.) \\ 3 Oak Ridge Institute for Science and Education, 1299 Bethel Valley Rd., Oak Ridge, TN 37830, USA \\ * Correspondence: mheather@iastate.edu
}

Citation: Lambert, Z.J.; Greenlee, J.J.; Cassmann, E.D.; West Greenlee, M.H. Differential Accumulation of Misfolded Prion Strains in Natural Hosts of Prion Diseases. Viruses 2021, 13, 2453. https://doi.org/10.3390/ v13122453

Academic Editors: Anthony E. Kincaid and Jason C. Bartz

Received: 5 November 2021

Accepted: 3 December 2021

Published: 7 December 2021

Publisher's Note: MDPI stays neutral with regard to jurisdictional claims in published maps and institutional affiliations.

Copyright: () 2021 by the authors. Licensee MDPI, Basel, Switzerland. This article is an open access article distributed under the terms and conditions of the Creative Commons Attribution (CC BY) license (https:// creativecommons.org/licenses/by/ $4.0 /)$.

\begin{abstract}
Prion diseases, also known as transmissible spongiform encephalopathies (TSEs), are a group of neurodegenerative protein misfolding diseases that invariably cause death. TSEs occur when the endogenous cellular prion protein $\left(\mathrm{PrP}^{\mathrm{C}}\right)$ misfolds to form the pathological prion protein $\left(\mathrm{PrP}^{\mathrm{Sc}}\right)$, which templates further conversion of $\mathrm{PrP}^{\mathrm{C}}$ to $\mathrm{PrP}^{\mathrm{Sc}}$, accumulates, and initiates a cascade of pathologic processes in cells and tissues. Different strains of prion disease within a species are thought to arise from the differential misfolding of the prion protein and have different clinical phenotypes. Different strains of prion disease may also result in differential accumulation of $\mathrm{PrPS}^{\mathrm{Sc}}$ in brain regions and tissues of natural hosts. Here, we review differential accumulation that occurs in the retinal ganglion cells, cerebellar cortex and white matter, and plexuses of the enteric nervous system in cattle with bovine spongiform encephalopathy, sheep and goats with scrapie, cervids with chronic wasting disease, and humans with prion diseases. By characterizing TSEs in their natural host, we can better understand the pathogenesis of different prion strains. This information is valuable in the pursuit of evaluating and discovering potential biomarkers and therapeutics for prion diseases.
\end{abstract}

Keywords: bovine spongiform encephalopathy; cerebellar cortex; chronic wasting disease; CreutzfeldtJakob disease; enteric nervous system; Gerstmann-Straussler-Scheinker disease; Kuru; prion neuroinvasion; retinal ganglion cells; scrapie

\section{Introduction}

Transmissible spongiform encephalopathies (TSEs) are a group of fatal, progressive neurodegenerative diseases that result from the misfolding and accumulation of endogenous prion protein $\left(\mathrm{PrP}^{\mathrm{Sc}}\right)$ [1]. Transmissible and spontaneous prion diseases have been described in a wide variety of species including humans [2], sheep [3-5], goats [6], mink [7], cattle [8], white-tailed deer [9], mule deer [9], elk [9,10] camels [11], moose [12], reindeer [13], red deer [14], sika deer [15], cats [16], and various zoo species [17,18].

A given prion disease within a species can have a range of phenotypes. Different phenotypes include, but are not limited to, differences in transmissibility within a species [19]; transmissibility between species [19]; disease time course [20]; most prominent clinical signs [21]; tissue, brain region [22] and cellular localization [23] of accumulated $\mathrm{PrP}^{\mathrm{Sc}}$.

Often, disease phenotypes within a given species are denoted as different 'strains' [24]. Strains in a natural host are commonly defined by the molecular weight profile of the $\mathrm{PrP}^{\mathrm{Sc}}$ [25], genotypes of susceptible hosts [23], age of disease onset [26,27], and distribution and intensity of misfolded $\operatorname{PrP}^{\mathrm{Sc}}[20,28]$. Because the molecular profile on a Western blot may be different depending on host species or strain of infection, to follow is a brief discussion of the significance. Following proteinase-K digestion of a sample homogenate 
containing misfolded prion protein, a Western blot results in three bands that are the di-, mono-, and unglycosylated isoforms (highest $\mathrm{kDa}$ to lowest $\mathrm{kDa}$, respectively) of the prion polypeptide. Increased glycosylation adds weight, which slows migration of the prion protein. Thus, the diglycosylated band has the highest $\mathrm{kDa}$, while the unglycosylated has the lowest $\mathrm{kDa}$. Different strains of prion disease in a given species may have different molecular weight profiles, particularly of the unglycosylated band, due to the differential cleavage by proteinase-K of the misfolded protein's n-terminal (reviewed in [29]).

Strains also may be grouped into what are referred to as 'classical' and 'atypical' based on proteinase K-resistant fragments, neuronal tropism, deposition patterns, and pathological lesion profile [30]. Classical cases of prion diseases tend to occur in groups of younger animals compared to atypical cases that tend to occur in individual older animals. Additionally, animals with classical cases of scrapie shed prions into the environment and thereby have a propensity for vertical and horizontal transmission under field conditions. Atypical cases of scrapie shed little to no prions into the environment, providing further evidence to support the spontaneous origin of atypical prion diseases. This, however, does not hold true in cases of cattle in which prions are not shed into the environment regardless of strain.

Rodent models have proven to be invaluable in isolating [31], identifying, and characterizing [32] strains of TSEs isolated from natural hosts [33]. However, to fully understand the pathogenesis of different TSE strains, they must also be characterized in their natural host. In many instances the character of $\mathrm{PrP}^{\mathrm{Sc}}$ immunoreactivity as well as cellular and subcellular localization of accumulated $\mathrm{PrP}^{\mathrm{Sc}}$ also differs between prion strains [34-36]. While Western blots provide information regarding protein size and strain following proteinase-K digestion, this review focuses on the differential localization and patterns of $\mathrm{PrP}^{\mathrm{Sc}}$ that are observed using immunohistochemistry. In this review, we focus on $\mathrm{PrP}^{\mathrm{Sc}}$ accumulation in three locations in the nervous system (retinal ganglion cells, cerebellar cortex, and enteric nervous system; see Figure 1). These three nervous system sites were selected based on the presence of robust literature that reports strain-dependent differential accumulation of $\operatorname{PrP}^{\mathrm{Sc}}$ within these structures. We discuss their utility in differentiating strains and better understanding the pathogenesis of bovine spongiform encephalopathy in cattle, scrapie in sheep and goats, and chronic wasting disease in cervids.
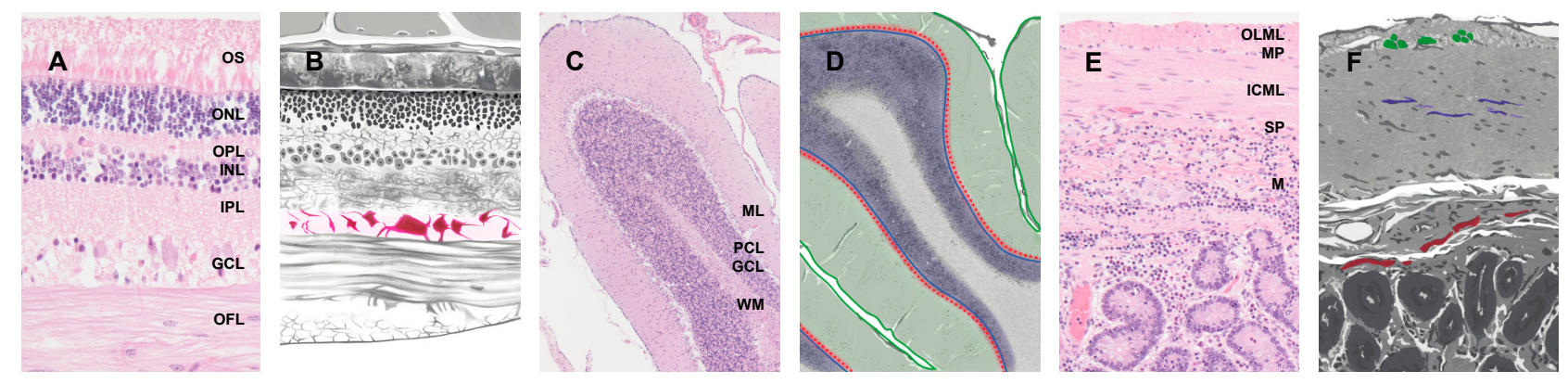

Figure 1. Retinal ganglion cells, cerebellar cortex and white matter, and plexuses of the enteric nervous system from animals with TSEs: (A) normal retina stained with hematoxylin and eosin. OS (outer segments of photoreceptor cells), ONL (outer nuclear layer), OPL (outer plexiform layer), INL (inner nuclear layer), IPL (inner plexiform layer), GCL (ganglion cell layer), OFL (optic fiber layer). Original magnification $20 \times($ B) illustrated retina with the retinal ganglion cells highlighted in red and ganglion cell layer highlighted in pink; (C) normal cerebellum stained with hematoxylin and eosin. ML (molecular layer), PCL (Purkinje cell layer), GCL (granule cell layer), WM (white matter). Original magnification $5 \times$; (D) illustrated cerebellum with the molecular layer outlined and highlighted in green, the Purkinje cell layer lined with red dots, the granule cell layer highlighted in purple, and the white matter highlighted in gray; (E) normal gut cross-section stained with hematoxylin and eosin. OLML (outer longitudinal muscle layer), MP (myenteric plexus), ICML (inner circular muscular layer), SP (submucosal plexus), M (mucosa). Original magnification 10×; (F) illustrated gut cross-section with the myenteric plexus highlighted in green, nerve fibers highlighted in purple, and submucosal plexus highlighted in red. Each image is original and previously unpublished. 


\section{Transmissible Spongiform Encephalopathies}

\subsection{Bovine Spongiform Encephalopathy}

Bovine spongiform encephalopathy (BSE) was first described in cattle in 1986 [37]. BSE is grouped into classical and atypical strains [38]. After Western blotting, the molecular weight profile of the unglycosylated band in atypical strains either lower (L-BSE) or higher (H-BSE) than the classical strain (C-BSE). C-BSE is transmissible to cattle [8], sheep [39], goats [39], and humans [40,41] among other animals [18] via consumption of infectious material and is the agent responsible for the mid-1980s to mid-1990s epizootic disease in the United Kingdom where over 178,000 cattle were diagnosed positive for C-BSE [42,43] and millions of cattle were depopulated. As of 2021, 232 people have died from vCJD worldwide [44]. While C-BSE is infectious following ingestion, all known atypical BSE strains are either spontaneous [38] or are inherited via polymorphism in the PRNP gene [45]. Atypical strains of BSE and scrapie have been identified in older animals [46] and do not appear to be easily transmitted via the oral route [47]. While atypical scrapie and H-BSE do not seem to be infectious to humans [48,49], evidence suggests that L-BSE has the potential to be transmissible to humans [49]. Relative to other species with prion diseases, cattle with BSE generally have little to no lymphoid distribution of $\mathrm{PrP}^{\mathrm{Sc}}$, except for tonsils and transiently in Peyer's patches [50,51]. Though atypical strains appear in older animals, experimental intracranial transmission of atypical strains of BSE results in a much shorter incubation time compared to C-BSE [52,53]. Unlike other species, polymorphisms in the PRNP gene of cattle are extremely rare, thus disease susceptibility and incubation time is not affected by an animal's genotype [53].

\subsection{Scrapie}

Scrapie is the prion disease of sheep and goats. The first records of scrapie date back to 1732 [54]. Following the first description of atypical (Nor-98) scrapie in 2003, discussion of scrapie strains is typically framed using classical and atypical scrapie in sheep [3]. There are differences in the molecular weight profile between classical and atypical strains of scrapie, as atypical scrapie has a smaller $\mathrm{PrP}^{\mathrm{Sc}}$ fragment, is more $\mathrm{PK}$ sensitive, and has 5 less intense Western blot bands compared to the three strong bands in classical scrapie $[3,4,26]$. In sheep, classical scrapie is spread primarily via horizontal transmission shortly after animals are born, though the average age of affected animals is 2-5 years of age [55], and there is widespread distribution of $\mathrm{PrP}^{\mathrm{Sc}}$ in lymphoid tissues [56,57]. Atypical scrapie in sheep appears to be sporadic, in that new cases appear in isolation, as opposed to a cluster of infected animals [3], and there is little to no accumulation of $\mathrm{PrP}^{\mathrm{Sc}}$ in the lymphoid system $[4,58]$. There are a number of polymorphisms in the PRNP gene of sheep that affect susceptibility and incubation time of different strains of scrapie (reviewed in $[26,59])$. Experimental and epidemiological evidence suggests that there is an extremely low likelihood that scrapie could be transmitted to humans $[29,60]$. Still, studies show that this low likelihood leaves room for the possibility of scrapie transmission to humans [61,62].

\subsection{Chronic Wasting Disease}

Chronic wasting disease (CWD) is the prion disease of deer and elk [63]. CWD was first identified in 1967 and was formally described in 1980 in captive mule deer and blacktailed deer [64]. Several CWD strains have been described [31,65-68]. In cervids with CWD, there is widespread accumulation of $\mathrm{PrP}^{\mathrm{Sc}}$ in lymphoid tissues [69]. There are several described polymorphisms in the PRNP gene that may influence disease susceptibility and incubation time [70]. CWD is extremely contagious between cervids, and while there is some evidence it is transmissible to other species [71-74], there is no evidence that it has been transmitted to humans $[9,75]$.

\subsection{Human Prion Diseases}

The most common prion disease in humans is Creutzfeldt-Jakob disease (CJD). CJD consists of multiple strains that include iatrogenic, variant, familial, and sporadic CJD 
(iCJD, vCJD, fCJD, and SCJD, respectively). The basis of these strains is their origin: acquired, inherited, or spontaneous [76]. For example, iCJD and vCJD are acquired. The cause of iatrogenic transmission of CJD is a surgical or medical procedure involving materials (pituitary hormones, dura mater graft, blood transfusion, etc.) contaminated with $\operatorname{PrP}^{\mathrm{Sc}}$ [76], while the variant strain is due to the ingestion of the misfolded prion protein from contaminated beef products [76]. Familial CJD is heritable and is the result of mutations at codons in the PRNP gene [76]. Lastly, sporadic CJD is spontaneous [76].

In 1974 the first case of iCJD was reported. This case was the first of many in which patients underwent a medical procedure with contaminated tissues or instruments and an incubation period of years to decades would follow. Due to subsequent public health and decontamination measures, iCJD does not pose the threat that it once did [77]. The first case of the vCJD epidemic in the United Kingdom was diagnosed in 1996, and evidence supports its cause being the consumption of cattle that were infected with BSE [40,41]. Susceptibility to vCJD is influenced by polymorphisms at codon 129 of the PRNP gene. For example, almost all vCJD cases are homozygous for methionine at codon 129 (MM129) [78-80]. Depending on the source, only one or two heterozygous individuals (MV129) have been reported to have vCJD $[78,81,82]$, and no one homozygous for valine has reported to have acquired $\operatorname{vCJD}[78,82]$.

Prion diseases in humans can be caused by inherited mutations in the PRNP gene, the most common mutation causing familial CJD is E200K. The number (200) refers to the codon of the PRNP at which a mutation occurs. The letters (E and K) refer to the oneletter code for amino acids (glutamic acid and lysine). In the case of E200K, the resulting amino acid is E (glutamic acid), rather than K (lysine), at codon 200 of the PRNP gene. Occasionally, E200K-129M may be used. This indicates that the individual is homozygous for M (methionine) at codon 129 of the PRNP gene. Familial CJD is an inherited form of prion disease caused by mutations in the PRNP gene. As mentioned, the most common mutation is E200K [83], which is homologous $[45,53]$ to the polymorphism observed in cattle with the hereditable E211K H-BSE [45]. At least 14 other autosomal dominant mutations causing fCJD have been reported [84].

Sporadic CJD has the greatest phenotypic variety and is genotype-dependent, as the majority of SCJD cases are homozygous for methionine (MM) at codon 129 of the PRNP gene [78]. The genotype of codon 129 of the PRNP gene and type of prion protein accumulation underlies the differentiation of subtypes of SCJD [85-88]. At codon 129 of the PRNP gene, people can be either heterozygous for methionine and valine (MV129) or homozygous for either methionine (MM129) or valine (VV129). Further, there are two types of prion accumulation that are designated Type 1 and 2. Type 1 prion accumulation has a PK cleavage site at residue 82 [86], a PK-resistant core of $21 \mathrm{kDa}$ [85], and has a smaller aggregation size following filtration (mean pore size $72 \mathrm{~nm}$ ) than Type 2 prion aggregation size [87]. Type 2 has a PK cleavage site at residue 97 [86], a PK-resistant core of $19 \mathrm{kDa}$ [85], and has a larger aggregation size following filtration (mean pore size $72 \mathrm{~nm}$ ) than Type 1 prion aggregation size [87]. In all, cases of sCJD can be broken down into the following pure subtypes based on genotype at codon 129 of the PRNP gene and type of prion accumulation: MM1, MV1, VV1, MM2, MV2, and VV2 [88-90]. Concurrent Type 1 and Type 2 prion accumulation occurs in over one-third of SCJD cases [88]. Prion strains can be differentiated by ratio of di-, mono-, and unglycosylated protein as well as relative molecular mass [91]. Interestingly, variants of sCJD can also present with visual disturbances, as people the Heidenhain variant of SCJD present with visual symptoms at disease onset along with early posterior cortical involvement [92].

Humans are susceptible to other prion diseases, such as Kuru, fatal familial insomnia (FFI), and Gerstmann-Straussler-Scheinker (GSS). Kuru, similar to vCJD, is an acquired prion disease. It is specific to the Fore people in New Guinea whose members participated in ritual cannibalism as a means of mourning and respect for their deceased kindred [93]. In the Fore language Kuru means trembling or shivering, which reflects the symptom onset of cerebellar ataxia and tremor [93]. Prevalence of the disease has dramatically decreased 
due to the termination of the practice [93]. FFI, similar to fCJD, is a hereditary prion disease due to a mutation at codon 178 of the PRNP gene that substitutes asparagine with aspartic acid (D178N) and is autosomal dominant [94]. Lastly, GSS is also a hereditary prion disease and can be caused by several mutations. These mutations include P102L (most common) [83], P105L, A117V, F198S, Q217R, Q212P, and D202N [95]. Mutations causing GSS are autosomal dominant. It has been reported that people with GSS may have symptomatic abnormal eye movements and optic atrophy, the latter of which is extremely rare in people with CJD [96-99].

\section{Retinal Ganglion Cells}

The retina displays functional and morphologic changes that are associated with protein misfolding diseases. Accordingly, the retina is of major interest to identify potential biomarkers for proteinopathies and neurodegenerative diseases, such as Parkinson's disease, Alzheimer's disease, Huntington's disease, and multiple sclerosis [100-108]. As such, the retina in cases of prion disease is also being studied [100,109]. It has been demonstrated that $\mathrm{PrP}^{\mathrm{Sc}}$ accumulates in the retina of cattle with BSE [47,52,53,100,110-112], sheep and goats with scrapie [58,109,111,113-124], cervids with CWD [121,125-133], and humans with prion diseases [134-137].

The eye is the most accessible part of the central nervous system. Thus, it can be imaged and functionally assessed using noninvasive techniques. Within the eye, the retina is responsible for transmitting visual stimuli to the brain for processing [138]. The retina is organized into functionally distinct cellular and synaptic layers of cells. $\mathrm{PrP}^{\mathrm{Sc}}$ differentially accumulates the retinal layers of animals with TSEs depending on factors ranging from strain of TSE to host genotype $[52,53,100,119,125,136,139,140]$. Once photons of light are transduced by the photoreceptor cells in the outer nuclear layer, the signal is transmitted to the inner nuclear layer and then the ganglion cell layer via the inner and outer plexiform layers. It is the axons of the retinal ganglion cells in the ganglion cell layer that exit the globe as the optic nerve to connect with subsequent parts of the visual pathway. Animals with TSEs accumulate $\mathrm{PrPS}^{\mathrm{Sc}}$ in the retina and multiple parts of the visual pathway $[109,125,141]$. Within the cellular and synaptic layers of the retina, $\mathrm{PrP}^{\mathrm{Sc}}$ accumulation is most common in the plexiform layers of the retina $[115,120,121,126,139,142,143]$ while the retinal ganglion cells demonstrate a strain-dependent variation of $\mathrm{PrP}^{\mathrm{Sc}}$ accumulation $[52,53,58,100,125]$.

There are strain-dependent differences in retinal function, prion accumulation, glial response, autophagic response, neuroinflammation, and other morphologic changes in the retinas of animals with TSEs [52,100,110]. Electroretinograms and optical coherence tomography have been used to assess functional and morphologic differences between strains of prion disease in cattle [100], sheep [109], and goats [122]. While electroretinograms measure the retina's response to visual stimuli, optical coherence tomography can be used to measure retinal thickness. The earliest functional difference associated with the accumulation of pathological prion protein is present in electroretinogram data 11 months prior to clinical signs of disease in cattle with BSE [100]. Strain-dependent functional differences include prolonged $b$-wave implicit time $[53,100,110,144]$ beginning at 12 months post inoculation [100] and continuing until clinical endpoint in cattle with C-BSE and H-BSE [100]. Additional data from optical coherence tomography shows retinal thinning in cattle $[53,100,110]$ that is first detectable at 12 months post inoculation in cattle inoculated with C-BSE and H-BSE [100] and continues until clinical endpoint [100,110]. Strains of BSE can also be differentiated by the types of immunostaining for $\mathrm{PrP}^{\mathrm{Sc}}$. In sheep, functional differences are evident by electroretinogram in the reduction of a-wave and b-wave amplitudes [109]. While not statistically significant, the average retinal thickness measured using optical coherence tomography in goats with scrapie trended lower than their scrapiefree counterparts [122]. $\mathrm{PrP}^{\mathrm{Sc}}$ accumulates in the retina of cervids with CWD; however, functional data are not available $[121,125,127]$. Electroretinogram data demonstrates that people with CJD have a significant reduction in b-wave amplitude $[145,146]$. Here we 
discuss the differential $\mathrm{PrP}^{\mathrm{Sc}}$ accumulation in the retinal ganglion cells (summarized in Tables 1-4).

Table 1. Immunolabelling patterns of PrPSc in the retinal ganglion cells in cattle with BSE.

\begin{tabular}{|c|c|c|}
\hline Strain & Genotype & Immunolabelling Pattern \\
\hline Classical & & $\begin{array}{c}\text { Rarely affected (West Greenlee 2015) ... decreased/much less prominent than E211K H-BSE } \\
\text { (Moore 2016) }\end{array}$ \\
\hline H-type & & $\begin{array}{l}\text { Large globular deposits (West Greenlee 2015) ... robust intracellular deposits, increased } \\
\text { compared to C-BSE (Mammadova 2020) ... intense granular in ganglion cell layer (Okada 2011) }\end{array}$ \\
\hline H-type & E211K & $\begin{array}{c}\text { Intense (Greenlee 2012) ... Increased accumulation compared to BSE-C, prominent intraneuronal } \\
\text { (Moore 2016) }\end{array}$ \\
\hline L-type & & Increased compared to BSE-C (Mammadova 2020) ... intracellular, intense punctate (Smith 2009) \\
\hline
\end{tabular}

Table 2. Immunolabelling patterns of $\mathrm{PrPSc}^{\mathrm{Sc}}$ in the retinal ganglion cells in sheep and goats with scrapie.

\begin{tabular}{|c|c|c|c|}
\hline Species & Strain & Genotype & Immunolabelling Pattern \\
\hline \multirow{17}{*}{ Sheep } & Classical (intracranial) & AA136 & Granular and coarse particulate deposits (Jeffrey 2014) \\
\hline & Classical (field) & & Granular (Regnier 2011) \\
\hline & \multirow{6}{*}{ Classical (No. 13-7) } & VV136 & Multifocal punctate in ganglion cell layer (Moore 2016) \\
\hline & & AV136 & $\begin{array}{c}\text { Multifocal punctate in ganglion cell layer (Moore 2016) ... } \\
\text { intense (Smith 2008) }\end{array}$ \\
\hline & & AA136 & $\begin{array}{l}\text { Multifocal punctate in ganglion cell layer (Moore 2016) ... } \\
\text { intense (Smith 2008) }\end{array}$ \\
\hline & & KK171 & - \\
\hline & & QK171 & - \\
\hline & & Q̄Q171 & - \\
\hline & \multirow{3}{*}{ Classical (x124) } & VV136 & $\begin{array}{l}\text { Multifocal punctate in ganglion cell layer (Hamir 2009, } \\
\text { Moore 2016) }\end{array}$ \\
\hline & & AV136 & $\begin{array}{l}\text { Multifocal punctate in ganglion cell layer (Hamir 2009, } \\
\text { Moore 2016) }\end{array}$ \\
\hline & & AA136 & $\begin{array}{l}\text { Multifocal punctate in ganglion cell layer (Hamir 2009, } \\
\text { Moore } 2016^{*} \text { ) }\end{array}$ \\
\hline & \multirow{6}{*}{ Atypical } & VRQ/ARQ & Minimal in ganglion cell layer (Cassmann 2021) \\
\hline & & ARQ/ARQ & Minimal in ganglion cell layer (Cassmann 2021) \\
\hline & & ARQ/ARR & Minimal in ganglion cell layer (Cassmann 2021) \\
\hline & & $\mathrm{AHQ} / \mathrm{ARQ}$ & - \\
\hline & & $\mathrm{AHQ} / \mathrm{AHQ}$ & - \\
\hline & & ARR/ARR & - \\
\hline Goat & Classical & & $\begin{array}{l}\text { Marked intraneuronal (Mammadova 2020) ... strong } \\
\text { prominent cytoplasmic (Valdez 2003) }\end{array}$ \\
\hline
\end{tabular}

(-) Not reported. * Intranasally inoculated were negative. Intracranially inoculated were positive.

Table 3. Immunolabelling patterns of $\mathrm{PrP}^{\mathrm{Sc}}$ in the retinal ganglion cells in cervids with CWD.

\begin{tabular}{ccc}
\hline Species & Genotype & Immunolabelling Pattern \\
\hline RME & 132MM & $\begin{array}{c}\text { Absence of intracytoplasmic staining (Spraker 2010) } \\
\text { Intracytoplasmic staining present (Spraker 2010) } \\
\end{array}$ \\
132ML & 132LL & $\begin{array}{c}\text { Prominent, heavy intracytoplasmic staining compared to ML } \\
\text { (Spraker 2010) }\end{array}$ \\
RD & & Intraneuronal (Moore 2016) \\
& Q95/G96 & Rare intraneuronal staining (Lambert, unpublished) \\
WTD & Q95/S96 & Rare intraneuronal staining (Lambert, unpublished) \\
& H95/G96 & - \\
MD & H95/S96 & Present in ganglion cell layer (Spraker 2002) \\
\hline
\end{tabular}


Table 4. Immunolabelling patterns of $\mathrm{PrP}^{\mathrm{Sc}}$ in the retinal ganglion cells in humans with $\mathrm{CJD}$.

\begin{tabular}{ccc}
\hline Strain & Subtype & Immunolabelling Pattern \\
\hline & MM1 & No intraneuronal staining (Head 2003, Takao 2018) \\
& MV1 & - \\
VCJD & MV1 & No intraneuronal staining (Head 2003, Takao 2018) \\
& MV2 & No intraneuronal staining (Head 2003, Takao 2018) \\
& VV2 & - \\
iCJD & & No intraneuronal staining (Head 2003, Takao 2018) \\
vCJD & &
\end{tabular}

(-) Not reported.

\subsection{Bovine Spongiform Encephalopathy}

Generally, retinal tissues from cattle experimentally inoculated with C-BSE have less immunoreactivity for $\mathrm{PrPSc}^{\mathrm{Sc}}$ as compared to H-BSE, E211K H-BSE, and L-BSE [52,53,100,147]. These strain-dependent differences in the extent and intensity of $\mathrm{PrP}^{\mathrm{Sc}}$ immunoreactivity in the retinas of cattle are illustrated and summarized in Figure 2A-D and Table 1. The deposition pattern in the retinas of cattle inoculated with C-BSE has been described as ranging from punctate and granular [52] to multifocal coalescing granular and globular [100] staining that is localized to the plexiform layers. Retinal tissues from cattle with atypical BSEs have more $\mathrm{PrP}^{\mathrm{Sc}}$ immunoreactivity compared to C-BSE [38,52]. $\mathrm{PrP}^{\mathrm{Sc}}$ immunoreactivity is more extensive, intense, and uniform in the retinas of cattle with atypical BSEs compared to cattle with C-BSE, especially in the plexiform layers [52,100]. While cattle with C-BSE have little to no $\mathrm{PrP}^{\mathrm{Sc}}$ immunoreactivity outside the plexiform layers, cattle with $\mathrm{H}$-BSE have staining in all retinal layers. In addition to globular deposits of misfolded prion protein in the photoreceptor cells, it also is reported that there are multifocal globular deposits in the nuclear layers of the retinas of cattle with H-BSE [52,100]. Cattle with H-BSE have intense granular $\mathrm{PrP}^{\mathrm{Sc}}$ accumulation in the plexiform layers [112]. Further differentiation between C-BSE and H-BSE can be conducted using the 12B2 antibody that is immunoreactive to tissues affected by H-BSE and not C-BSE [100]. Using the 12B2 antibody, tissues from cattle with C-BSE cannot be differentiated from control animal tissues while those with H-BSE displayed immunoreactivity throughout the retina [100]. The deposition pattern of $\mathrm{PrPSc}^{\mathrm{S}}$ in retinal ganglion cells of cattle experimentally inoculated with $\mathrm{H}-\mathrm{BSE}$ is similar to that of cattle inoculated with E211K H-BSE, both demonstrating prominent intracellular accumulation [53]. Deposition of $\mathrm{PrP}^{\mathrm{Sc}}$ is intense and abundant in the plexiform layers in cattle inoculated with E211K H-BSE (Figure 2D) [53,110]. In one study using three isolates of L-BSE (French low-type, Canadian low-type, and Italian BASE), no differences in PrPSc deposition in the retina were reported between these isolates of L-BSE [52,148]. Similar to H-BSE, the deposition pattern in cattle experimentally inoculated with L-BSE is greater in amount and distribution compared to cattle inoculated with C-BSE [38,52]. Similar to $\mathrm{H}-\mathrm{BSE}$, the retinas affected by L-BSE have intense punctate deposition that is reported to be more intense and uniform in the plexiform layers compared to those of C-BSE [52,100]. Compared to cattle with H-BSE, the retinal layers of cattle with L-BSE have fewer deposits of PrPSc; however, these deposits are still greater than cattle with C-BSE [52]. Cattle with L-BSE demonstrate intense punctate $\mathrm{PrP}^{\mathrm{Sc}}$ accumulation in the plexiform layers of the retina [144]. 


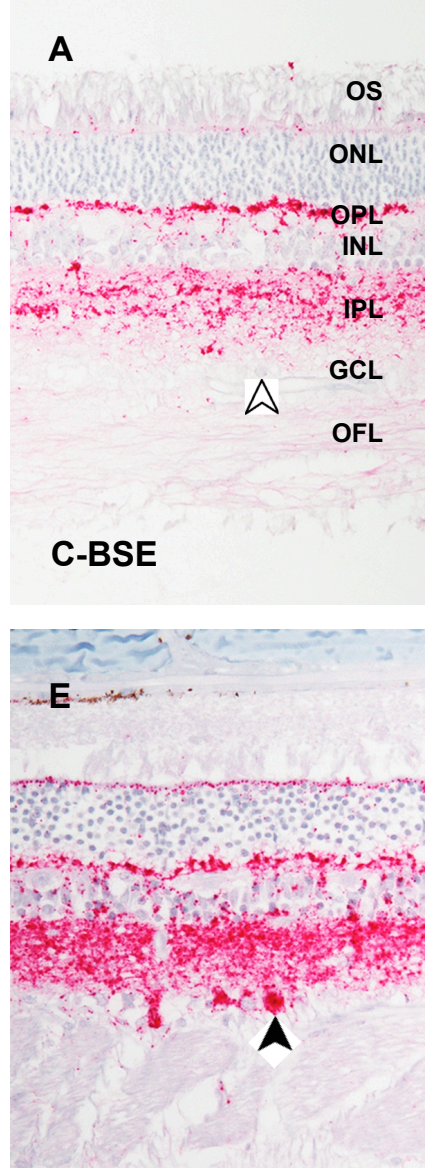

No. 13-7

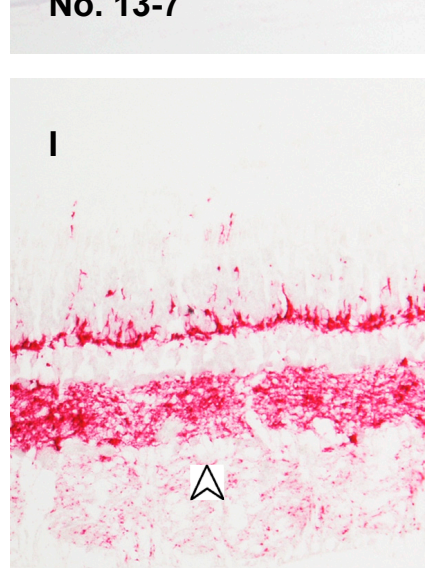

CWD MM132 elk
B

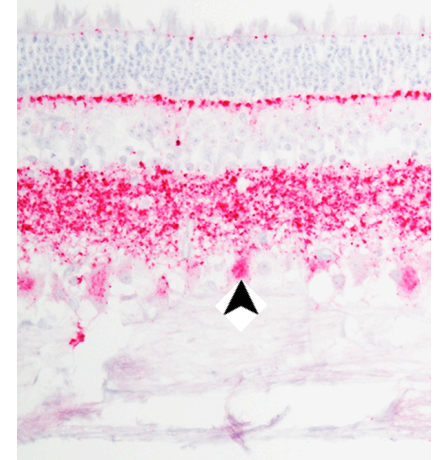

L-BSE

F

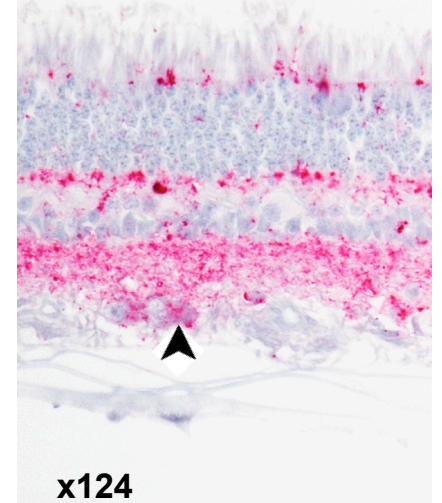

$x 124$

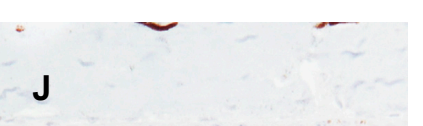

CWD LL132 elk
C

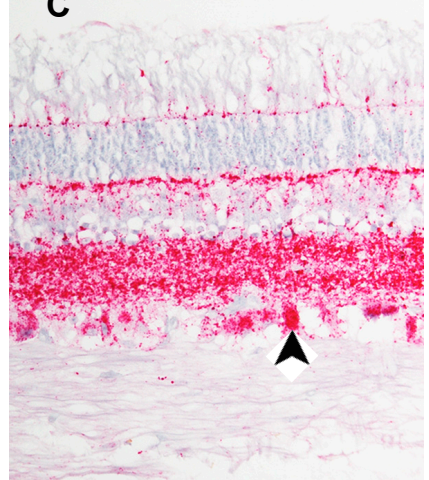

H-BSE

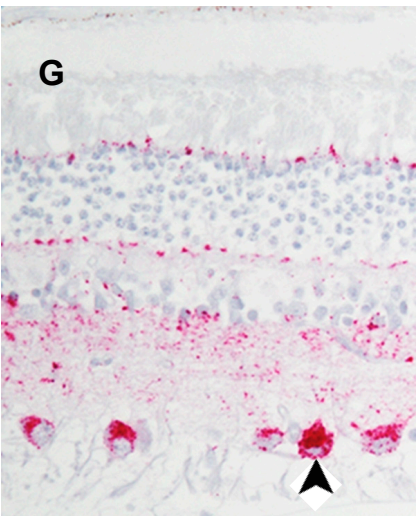

Goat scrapie
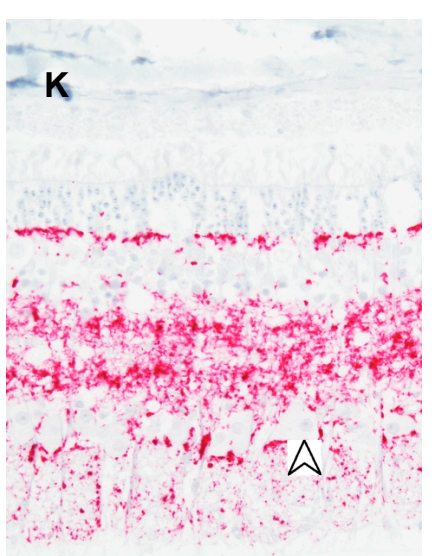

CWD WTD

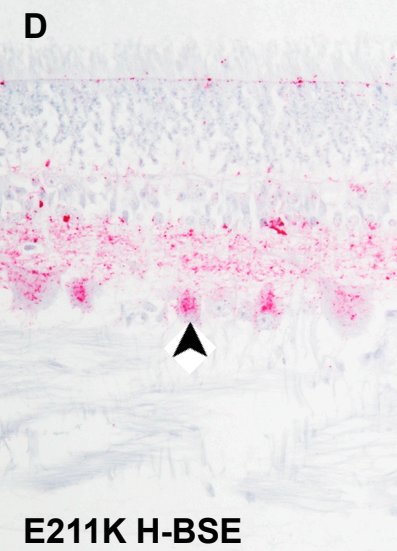

H

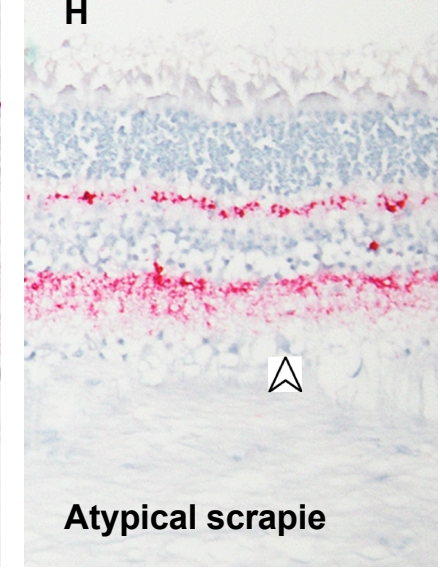

L

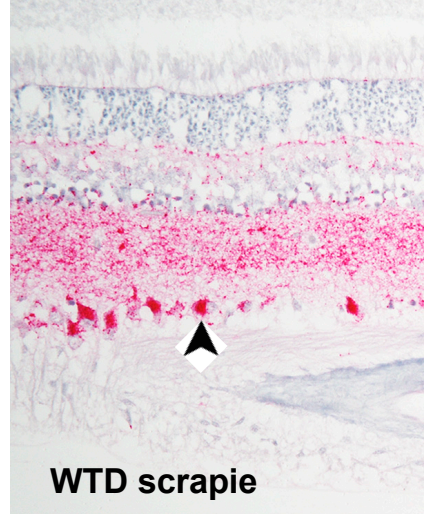

Figure 2. Strain-dependent differential accumulation of $\mathrm{PrPSc}^{\mathrm{Sc}}$ in the retinas of animals with TSEs: (A-D) retinas of cattle with BSE. Cattle with L-BSE, H-BSE, and E211K H-BSE have intraneuronal staining of $\mathrm{PrP}^{\mathrm{Sc}}$ in the cell body of the retinal ganglion cells (solid arrows) while cattle with C-BSE do not (open arrow). C-BSE (classical bovine spongiform encephalopathy), L-BSE (low-type bovine spongiform encephalopathy), H-BSE (high-type bovine spongiform encephalopathy), E211K H-BSE (high-type bovine spongiform encephalopathy with EK polymorphism at codon 211 of PRNP gene); (E-H) retinas of sheep and goats with classical and atypical scrapie. Sheep and goats with classical scrapie strains have immunoreactivity against $\mathrm{PrPSc}^{\mathrm{Sc}}$ in the cell body of retinal ganglion cells (solid arrows). Sheep with atypical scrapie do not accumulate $\mathrm{PrPSc}$ in the cell body of retinal ganglion cells (open arrow). No. 13-7 (classical scrapie strain in sheep), x124 (classical scrapie strain in sheep), goat scrapie (classical scrapie in goat), atypical scrapie (atypical scrapie in sheep); (I-L) retinas from Rocky Mountain 
elk with CWD and white-tailed deer with CWD or scrapie. Rocky Mountain elk that are of the LL132 genotype have PrPSc accumulation in the cell body of retinal ganglion cells (solid arrow) while those expressing MM132 do not (open arrow). White-tailed deer with CWD does not accumulate $\mathrm{PrP}^{\mathrm{Sc}}$ in the retinal ganglion cells (open arrow), while white-tailed deer experimentally inoculated with scrapie do accumulate $\mathrm{PrP}^{\mathrm{Sc}}$ in retinal ganglion cells (solid arrow). CWD MM132 elk (chronic wasting disease in elk expressing homozygous methionine at codon 132 of the PRNP gene), CWDLL132 elk (chronic wasting disease in elk expressing homozygous leucine at codon 132 of the PRNP gene), CWD WTD (chronic wasting disease in white-tailed deer), WTD scrapie (white-tailed deer inoculated with classical scrapie). Original magnification $20 \times$. Each image is original and previously unpublished.

The greatest difference in staining between strains of BSE can be observed in the retinal ganglion cells. Intraneuronal staining of the retinal ganglion cells in cases of cattle with C-BSE is less than atypical cases $[52,53,100]$. Cattle with H-BSE have intense granular $\mathrm{PrP}^{\mathrm{Sc}}$ accumulation in the ganglion cell layer [112] along with hallmark intense globular [100] and robust intracellular [52] $\mathrm{PrP}^{\mathrm{Sc}}$ deposits present in the retinal ganglion cells (Figure 2C) [52,100]. Deposition of $\mathrm{PrP}^{\mathrm{Sc}}$ is a prominent feature in the cell bodies of the retinal ganglion cells in cattle inoculated with E211K H-BSE (Figure 2D) [53,110]. Importantly, the retinal ganglion cells of cattle with L-BSE have intense punctate [144] and robust intracellular [52] deposits of misfolded prion protein (Figure 2B). Overall, $\mathrm{PrP}^{\mathrm{Sc}}$ accumulation is differential in the cell bodies of retinal ganglion cells of cattle with atypical BSEs that is increased compared to cattle with C-BSE.

\subsection{Scrapie}

There is differential accumulation of misfolded prion protein in the retinas of sheep with classical and atypical scrapie. These differences are best demonstrated in Figure 2E-H and Table 2. Of the two US isolates of classical scrapie in sheep, No. 13-7 and x124 [59,115,149], no differences were reported in the $\mathrm{PrP}^{\mathrm{Sc}}$ deposition patterns between retinas [115]. In sheep oronasally inoculated with the No. 13-7 classical strain, sheep homozygous for lysine at codon 171 (KK171) of the PRNP gene were resistant, while sheep with glutamine at codon 171 (QK171 or QQ171) accumulated $\mathrm{PrP}^{\mathrm{Sc}}$ in the retina [119]. The plexiform layers of the retinas in sheep with classical scrapie have confluent, punctate, globular, intense, and coarse particulate deposition patterns [109,113-116,118,124]. In sheep with classical scrapie, the photoreceptor cell layer has multifocal punctate $[114,115,118]$ deposits with granules in the inner segments of the photoreceptor cell layer $[109,113,116,150]$. Interestingly, sheep of AA136 genotype and oronasally inoculated with x124 classical scrapie were resistant while those intracranially inoculated accumulated $\mathrm{PrP}^{\mathrm{Sc}}$ in the retina [115]. The retinas of the No. 13-7-inoculated counterparts of this study all had immunoreactivity for $\operatorname{PrP}^{\mathrm{Sc}}$ [115]. Evidence suggests that $\mathrm{PrP}^{\mathrm{Sc}}$ accumulates differently in the retinas of sheep with atypical scrapie compared to those with classical scrapie [58] although the retina is not otherwise reported. In the retinas of sheep with atypical scrapie there is prominent immunoreactivity for $\mathrm{PrP}^{\mathrm{Sc}}$ in the plexiform layers with minimal staining in the nuclear layers (Figure 2H) [58]. Results of immunohistochemical staining of the retina were not reported in other strains of scrapie such as CH1641 and SSBP1 [151]. In the retinas of goats with classical scrapie, the $\mathrm{PrP}^{\mathrm{Sc}}$ deposition pattern reflects what is observed in sheep with classical scrapie [122,123]. $\mathrm{PrPSc}^{\mathrm{Sc}}$ accumulation is intense and extensive the goats with classical scrapie [122,123]. Along these lines, there is strong [123] particulate [122] accumulation in the plexiform layers and weak accumulation in the nuclear layers [123].

Retinal tissues from sheep with classical scrapie have $\mathrm{PrP}^{\mathrm{Sc}}$ immunoreactivity in the cell bodies of retinal ganglion cells while RGC immunostaining negligible in sheep with atypical scrapie. The ganglion cell layer in sheep with classical scrapie has multifocal punctate deposits of $\operatorname{PrP}^{S^{c}}[109,113-116,118]$ with granular $[109,124]$ and coarse particulate [116,124] deposits occurring in the cell bodies of retinal ganglion cells [113] (Figure $2 \mathrm{E}-\mathrm{G}$ ). In the retinas of sheep with atypical scrapie, there is minimal staining in the ganglion cell layer (Figure 2H) [58]. In goats with classical scrapie, there is intense accumulation in the ganglion cell layer [122] and strong prominent cytoplasmic deposition in retinal ganglion cells [123]. Similarly, intense intraneuronal $\mathrm{PrP}^{\mathrm{Sc}}$ accumulation is 
reported in the retinal ganglion cells of goats with classical scrapie (Figure 2G) [122,123]. In summary, increased $\mathrm{PrP}^{\mathrm{Sc}}$ accumulation occurs in the retinal ganglion cells of sheep and goats with classical scrapie and not in those with atypical scrapie.

\subsection{Chronic Wasting Disease}

$\mathrm{PrP}^{\mathrm{Sc}}$ accumulates in the retinas of cervids with CWD $[121,125,127-133]$ and is different depending on the species affected by CWD and genotype within a species. For example, the degree of $\operatorname{PrP}^{\mathrm{Sc}}$ accumulation in the retinas of Rocky Mountain elk $[125,130,132]$ is genotype- and strain-dependent based on the polymorphism at codon 132 of the PRNP gene $[125,130]$. These differences are best demonstrated in Figure 2I,J and Table 3. The most common genotype at codon 132 in captive and free-ranging Rocky Mountain elk is homozygous methionine (MM132) [125]. When elk of the MM132 genotype have CWD, their retinas display intense staining in the plexiform layers and no intraneuronal $\mathrm{PrP}^{\mathrm{Sc}}$ immunoreactivity in the retinal ganglion cells $[125,130]$. The retinas of Rocky Mountain elk heterozygous at codon 132 of the PRNP gene (ML132) demonstrate intracytoplasmic accumulation of $\mathrm{PrP}^{\mathrm{Sc}}$ [125]. Rocky Mountain elk homozygous for leucine at the codon 132 of the PRNP gene (LL132) have heavy intraneuronal PrPSc accumulation in the cell bodies of retinal ganglion cells compared to MM132 (Figure 2I,J) [130]. Passage of the CWD agent through LL132 elk may result in a strain separate than what is isolated from ML132 and MM132 elk [31]. Overall, retinal tissues from Rocky Mountain elk with the LL132 strain have more extensive $\mathrm{PrP}^{\mathrm{Sc}}$ immunoreactivity when compared to other genotypes and strains.

Other cervids with CWD also accumulate $\mathrm{PrP}^{\mathrm{Sc}}$ in the retina. Misfolded prion protein accumulates in the retinas of white-tailed deer [127-129,133], reindeer [131,132], and mule deer [121]. Within each species, no differential $\mathrm{PrPS}^{\mathrm{Sc}}$ accumulation has been reported between retinas in a genotype- or strain-dependent manner. Reindeer accumulate $\mathrm{PrP}^{\mathrm{Sc}}$ in the retina [131,132] with intraneuronal immunoreactivity in the retinal ganglion cells [132]. Immunoreactivity for $\mathrm{PrP}^{\mathrm{Sc}}$ in the retinas of reindeer can be punctate, particulate, and coalescing deposits in the plexiform layers with scattered intramicroglial deposits [132]. Mule deer accumulate $\mathrm{PrP}^{\mathrm{Sc}}$ in the retina [121]. While prion accumulation is reported in the plexiform and ganglion cell layers of mule deer [121], there has been no further characterization of this staining. Polymorphisms exist at codons 95 and 96 of the PRNP gene in white-tailed deer, but there were no differences in $\operatorname{PrP}^{\mathrm{Sc}}$ immunoreactivity based on genotype [127-129,133]. $\mathrm{PrP}^{\mathrm{Sc}}$ staining patterns in the retinas of white-tailed deer are diffuse granular in the plexiform layers $[127,129]$ and fine multifocal in the ganglion cell layer with little to no accumulation in the retinal ganglion cells as seen in Figure 2K [128]. In contrast, white-tailed deer inoculated with the sheep scrapie agent have robust accumulation of $\mathrm{PrP}^{\mathrm{Sc}}$ in the cell bodies of retinal ganglion cells (Figure 2L) [152]. This is notable because it provides a way to differentiate CWD from scrapie in white-tailed deer.

\subsection{Human Prion Diseases}

$\mathrm{PrP}^{\mathrm{Sc}}$ accumulation has been demonstrated in the retinas of people with CJD [134-137]. These differences are summarized in Table 4 . In cases of the sporadic, variant, familial, and iatrogenic strains of $\mathrm{CJD}, \mathrm{PrP}^{\mathrm{Sc}}$ accumulation occurs primarily as strong uniform staining in the plexiform layers [134-136]. In people with the most common subtype of sCJD (MM1), the plexiform layers are reported to be immunoreactive in a focal granular pattern [134]. There is no intraneuronal staining of the retinal ganglion cells reported in people with sCJD and vCJD $[135,136]$. PrPSc accumulation is both genotype- and strain dependent because people with sCJD of the most common subtype (MM1) have less $\mathrm{PrP}^{\mathrm{Sc}}$ accumulation in the retina compared to both people with sCJD of a less common subtype and vCJD [134]. Supporting strain-dependent differential $\mathrm{PrP}^{\mathrm{Sc}}$ accumulation, people with $\mathrm{vCJD}$ have a higher concentration of $\mathrm{PrP}^{\mathrm{Sc}}$ in the retina relative to brain than people with sCJD [137]. The accumulation of $\mathrm{PrP}^{\mathrm{Sc}}$ in the retina has not been reported in studies of people with GSS $[95,153,154]$ or Kuru [155-158]. 


\section{Cerebellar Cortex and White Matter}

Depending on the strain of TSE and host genotype, misfolded prion protein accumulates differentially in the cerebellar cortex of cattle with BSE $[53,159,160]$, sheep and goats with scrapie $[23,26,29,161]$, cervids with CWD [129,132,162], and humans with CJD, GSS, and Kuru $[95,158,163]$. These strain-dependent differences include the intensity of $\mathrm{PrP}^{\mathrm{Sc}}$ accumulation relative to the brainstem at the level of the obex $[23,26,29,160,161]$, immunolabelling pattern $[129,159,161]$, cerebellar cortex layer with greatest $\mathrm{PrP}^{\mathrm{Sc}}$ accumulation $[26,129,159]$, and molecular profile [110]. Within the cerebellum, the cerebellar cortex consists of three cellular layers: the molecular layer, Purkinje cell layer, and granule cell layer. Immediately deep to the granule cell layer of the cerebellar cortex is the cerebellar white matter that allows axonal fibers to enter and exit the cerebellum for communication with the cerebrum and body.

The role of the cerebellar cortex is to receive and integrate information from the brain and body in order to produce coordinated goal-directed movements as well as maintain posture and balance. This role of the cerebellar cortex includes correcting errors in voluntary movement via receiving signals from the cerebrum and feedback from the body, which it can then integrate into appropriate efferent signals to ultimately synapse with somatic muscle fibers. Lesions in the cerebellum manifest as errors in goal-directed movement and posture. For example, animals or people may present with uncoordinated flexor and extensor muscles, ataxia, or hypermetria. These manifestations of cerebellar dysfunction are evident clinical signs in animals and people with prion diseases $[4,58,164-166]$. However, clinical signs do not always reflect the level of $\mathrm{PrP}^{\mathrm{Sc}}$ accumulation in the cerebellum. For example, goats with scrapie may accumulate a similar level of $\mathrm{PrPSc}^{\mathrm{Sc}}$ in the cerebellum compared to sheep; however, they may not present with cerebellar signs [164]. Still, the molecular and granule cell layers of the cerebellar cortex display differential accumulation of misfolded prion protein. Here, when discussing the intensity of misfolded prion accumulation in the cerebellum, it is always relative to the brainstem at the level of the obex. We summarize the differential accumulation that occurs in the cerebellar cortex of animal and humans with prion disease (Tables 5-9).

Table 5. Immunolabelling patterns of $\mathrm{PrPSc}^{\mathrm{Sc}}$ in the cerebellar cortex in cattle with BSE.

\begin{tabular}{|c|c|c|c|c|c|}
\hline Strain & Genotype & $\begin{array}{c}\text { Relative } \\
\text { Accumulation }\end{array}$ & Molecular Layer & $\begin{array}{l}\text { Purkinje } \\
\text { Cell Layer }\end{array}$ & Granule Cell Layer \\
\hline Classical & & $\begin{array}{l}\text { Lower than brainstem } \\
\text { at level of obex (Polak } \\
\text { 2012, Vidal 2006) }\end{array}$ & $\begin{array}{c}\text { Prominent stellate and linear } \\
\text { (Moore 2016) ... moderate } \\
\text { stellate; apparent perineuronal, } \\
\text { fine punctate, coarse particulate; } \\
\text { barely apparent intraneuronal } \\
\text { (Siso 2004)... moderate or high } \\
\text { stellate (Okada 2011) }\end{array}$ & - & $\begin{array}{l}\text { Fine and coarse granular } \\
\text { to aggregated } \\
\text { (Moore 2016) }\end{array}$ \\
\hline High-type & & $\begin{array}{l}\text { Lower than brainstem } \\
\text { at level of obex (Polak } \\
\text { 2012) }\end{array}$ & $\begin{array}{l}\text { Minimal and less uniformly } \\
\text { distributed compared to BSE-L } \\
\text { (Konold 2012) ... prominent } \\
\text { stellate labeling (Okada 2011) }\end{array}$ & - & $\begin{array}{l}\text { Minimal and less } \\
\text { uniformly distributed } \\
\text { compared to BSE-L } \\
\text { (Konold 2012) ... } \\
\text { prominent stellate } \\
\text { labeling (Okada 2011), }\end{array}$ \\
\hline High-type & E211K & - & $\begin{array}{l}\text { Fine granular and stellate } \\
\text { (Moore 2016) ... small, } \\
\text { multifocal clumps of granular } \\
\text { and particulate staining } \\
\text { (Greenlee 2012) }\end{array}$ & - & $\begin{array}{l}\text { coarse granular } \\
\text { (Moore 2016) ... scant; } \\
\text { small, multifocal clumps } \\
\text { of granular and } \\
\text { particulate staining } \\
\text { (Greenlee 2012) }\end{array}$ \\
\hline Low-type & & $\begin{array}{l}\text { Equal to brainstem at } \\
\text { level of obex (Polak } \\
\text { 2012, Okada 2017) }\end{array}$ & $\begin{array}{l}\text { Very homogenous involvement, } \\
\text { diffuse and even (Konold 2012) }\end{array}$ & - & $\begin{array}{l}\text { Very homogenous } \\
\text { involvement, diffuse } \\
\text { and even (Konold 2012) }\end{array}$ \\
\hline
\end{tabular}

(-) Not reported. 
Table 6. Immunolabelling patterns of $\mathrm{PrPSc}^{\mathrm{Sc}}$ in the cerebellar cortex in sheep and goats with classical scrapie.

\begin{tabular}{|c|c|c|c|c|c|c|}
\hline Species & Strain & Genotype & $\begin{array}{c}\text { Relative } \\
\text { Accumulation }\end{array}$ & Molecular Layer & $\begin{array}{c}\text { Purkinje Cell } \\
\text { Layer }\end{array}$ & Granule Cell Layer \\
\hline \multirow{9}{*}{ Sheep } & \multirow{6}{*}{$\begin{array}{c}\text { Classical (No. } \\
\text { 13-7) }\end{array}$} & VV136 & - & - & - & - \\
\hline & & AV136 & - & $\begin{array}{c}\text { Intense, } \\
\text { multifocal } \\
\text { (Greenlee 2019) }\end{array}$ & - & $\begin{array}{c}\text { Intense, stronger } \\
\text { than molecular layer } \\
\text { (Greenlee 2019) }\end{array}$ \\
\hline & & AA136 & - & - & - & Moderate but \\
\hline & & KK171 & - & $\begin{array}{l}\text { Scant punctate, } \\
\text { granular, and } \\
\text { stellate deposits } \\
\text { (Cassmann 2019) }\end{array}$ & $\begin{array}{l}\text { Small amount of } \\
\text { intraneuronal } \\
\text { (Cassmann 2019) }\end{array}$ & $\begin{array}{c}\text { variable amounts of } \\
\text { granular, } \\
\text { intraneuronal, and } \\
\text { intraglial } \\
\text { (Cassmann 2019) }\end{array}$ \\
\hline & & QK171 & - & $\begin{array}{l}\text { Scant punctate, } \\
\text { granular, and } \\
\text { stellate deposits } \\
\text { (Cassmann 2019) }\end{array}$ & $\begin{array}{l}\text { Small amount of } \\
\text { intraneuronal } \\
\text { (Cassmann 2019) }\end{array}$ & $\begin{array}{c}\text { variable amounts of } \\
\text { granular, } \\
\text { intraneuronal, and } \\
\text { intraglial } \\
\text { (Cassmann 2019) }\end{array}$ \\
\hline & & QQ171 & - & $\begin{array}{l}\text { Scant punctate, } \\
\text { granular, and } \\
\text { stellate deposits } \\
\text { (Cassmann 2019) }\end{array}$ & $\begin{array}{l}\text { Small amount of } \\
\text { intraneuronal } \\
\text { (Cassmann 2019) }\end{array}$ & $\begin{array}{l}\text { Moderate but } \\
\text { variable amounts of } \\
\text { granular, } \\
\text { intraneuronal, and } \\
\text { intraglial } \\
\text { (Cassmann 2019) }\end{array}$ \\
\hline & \multirow{3}{*}{ Classical (x124) } & VV136 & - & - & - & - \\
\hline & & AV136 & - & - & - & - \\
\hline & & AA136 & - & - & - & - \\
\hline Goat & Classical & & - & $\begin{array}{c}\text { Subpial } \\
\text { (Mammadova } \\
\text { 2020)... strong } \\
\text { and widespread } \\
\text { cytoplasmic im- } \\
\text { munoreactivity of } \\
\text { small neurons } \\
\text { (Valdez 2003) }\end{array}$ & $\begin{array}{l}\text { Strong and } \\
\text { widespread } \\
\text { cytoplasmic im- } \\
\text { munoreactivity of } \\
\text { Purkinje cells } \\
\text { (Valdez 2003) }\end{array}$ & $\begin{array}{c}\text { Strong and } \\
\text { widespread } \\
\text { cytoplasmic } \\
\text { immunoreactivity of } \\
\text { small neurons } \\
\text { (Valdez 2003) }\end{array}$ \\
\hline
\end{tabular}

(-) not reported.

Table 7. Immunolabelling patterns of $\mathrm{PrP}^{\mathrm{Sc}}$ in the cerebellar cortex in sheep with atypical scrapie.

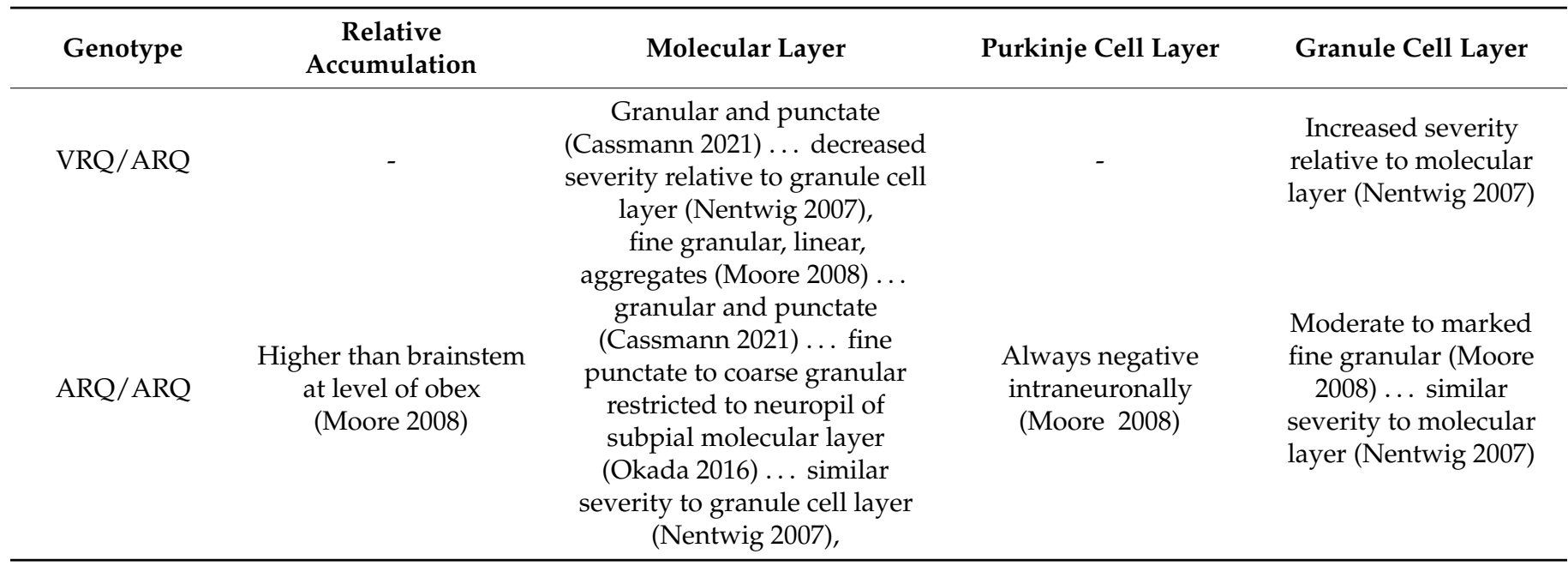


Table 7. Cont.

\begin{tabular}{|c|c|c|c|c|}
\hline Genotype & $\begin{array}{c}\text { Relative } \\
\text { Accumulation }\end{array}$ & Molecular Layer & Purkinje Cell Layer & Granule Cell Layer \\
\hline ARQ/ARR & - & $\begin{array}{l}\text { intense, stronger than granule } \\
\text { cell layer (Greenlee 2019) ... } \\
\text { granular and punctate } \\
\text { (Cassmann 2021) }\end{array}$ & - & Intense (Greenlee 2019) \\
\hline AHQ/ARQ & $\begin{array}{l}\text { Higher than brainstem } \\
\text { at level of obex } \\
\text { (Benestad 2003, } \\
\text { Moore 2008) }\end{array}$ & $\begin{array}{c}\text { Fine granular, linear, } \\
\text { aggregates (Moore 2008) ... } \\
\text { intense and marked synaptic } \\
\text { (Benestad 2003) ... similar } \\
\text { severity to granule cell layer } \\
\text { (Nentwig 2007) }\end{array}$ & $\begin{array}{l}\text { Always negative } \\
\text { intraneuronally } \\
\text { (Moore 2008) }\end{array}$ & $\begin{array}{l}\text { Moderate to marked } \\
\text { fine granular } \\
\text { (Moore 2008) ... } \\
\text { pronounced and } \\
\text { widspread (Benestad } \\
\text { 2003) ... similar } \\
\text { severity to molecular } \\
\text { layer (Nentwig 2007) }\end{array}$ \\
\hline AHQ/AHQ & $\begin{array}{l}\text { Higher than brainstem } \\
\text { at level of obex } \\
\text { (Benestad 2003, } \\
\text { Moore 2008) }\end{array}$ & $\begin{array}{c}\text { Fine granular, linear, } \\
\text { aggregates (Moore 2008) ... } \\
\text { intense and marked synaptic } \\
\quad \text { (Benestad 2003) }\end{array}$ & $\begin{array}{l}\text { Always negative } \\
\text { intraneuronally } \\
\text { (Moore 2008) }\end{array}$ & $\begin{array}{l}\text { Moderate to marked } \\
\text { fine granular (Moore } \\
\text { 2008) ... pronounced } \\
\text { and widspread } \\
\text { (Benestad 2003) }\end{array}$ \\
\hline ARR/AHQ & $\begin{array}{l}\text { Higher than brainstem } \\
\text { at level of obex } \\
\text { (Moore 2008) }\end{array}$ & $\begin{array}{c}\text { Fine granular, linear, } \\
\text { aggregates (Moore 2008) }\end{array}$ & $\begin{array}{l}\text { Always negative } \\
\text { intraneuronally } \\
\text { (Moore 2008) }\end{array}$ & $\begin{array}{l}\text { Moderate to marked } \\
\text { fine granular } \\
\text { (Moore 2008) }\end{array}$ \\
\hline ARR/ARR & $\begin{array}{l}\text { Higher than brainstem } \\
\text { at level of obex } \\
\text { (Kittelberger 2010) }\end{array}$ & $\begin{array}{c}\text { Fine granular, linear, } \\
\text { aggregates (Moore 2008) ... } \\
\text { increased severity relative } \\
\text { granule cell layer } \\
\text { (Nentwig 2007) }\end{array}$ & $\begin{array}{l}\text { Always negative } \\
\text { intraneuronally } \\
\text { (Moore 2008) }\end{array}$ & $\begin{array}{l}\text { Moderate to marked } \\
\text { fine granular } \\
\text { (Moore 2008) ... } \\
\text { decreased severity } \\
\text { relative to molecular } \\
\text { layer (Nentwig 2007) }\end{array}$ \\
\hline
\end{tabular}

(-) Not reported.

Table 8. Immunolabelling patterns of $\mathrm{PrP}^{\mathrm{Sc}}$ in the cerebellar cortex in cervids with CWD.

\begin{tabular}{cccccc}
\hline Species & Genotype & $\begin{array}{c}\text { Relative } \\
\text { Accumulation }\end{array}$ & Molecular Layer & $\begin{array}{c}\text { Purkinje Cell } \\
\text { Layer }\end{array}$ & Granule Cell Layer \\
\hline RME & 132MM & - & - & - & - \\
& 132ML & - & - & - & - \\
132LL & - & Lower than & Punctate, particulate \\
aggregated deposits \\
RD
\end{tabular}


Table 8. Cont.

\begin{tabular}{|c|c|c|c|c|c|}
\hline Species & Genotype & $\begin{array}{c}\text { Relative } \\
\text { Accumulation }\end{array}$ & Molecular Layer & $\begin{array}{c}\text { Purkinje Cell } \\
\text { Layer }\end{array}$ & Granule Cell Layer \\
\hline & \multirow[t]{2}{*}{ H95/S96 } & - & $\begin{array}{c}\text { More intense } \\
\text { immunolabeling than } \\
\text { other genotypes, } \\
\text { conspicuous stellate } \\
\text { aggregates (Otero 2019) }\end{array}$ & - & $\begin{array}{c}\text { Fine punctate and coarse } \\
\text { granular deposits } \\
\text { homogeneously } \\
\text { distributed (Otero 2019) }\end{array}$ \\
\hline MD & & - & $\begin{array}{l}\text { Amyloid plaques } \\
\text { (Guiroy 1991) }\end{array}$ & - & $\begin{array}{c}\text { Amyloid plaques, } \\
\text { immunoreactive } \\
\text { material also in neuronal } \\
\text { perikarya (Guiroy 1991) }\end{array}$ \\
\hline
\end{tabular}

(-) Not reported.

Table 9. Immunolabelling patterns of PrPSc in the cerebellar cortex in humans with prion disease.

\begin{tabular}{|c|c|c|c|c|c|}
\hline Strain & Subtype & $\begin{array}{c}\text { Relative } \\
\text { Accumulation }\end{array}$ & Molecular Layer & $\begin{array}{c}\text { Purkinje Cell } \\
\text { Layer }\end{array}$ & Granule Cell Layer \\
\hline \multirow{7}{*}{ sCJD } & NA & - & $\begin{array}{l}\text { Diffuse and fine dotted } \\
\text { deposits, synatpic type } \\
\text { (Yang 1999) ... diffuse } \\
\text { irregular plaque-like } \\
\text { deposits, punctate } \\
\text { synaptic-like deposits, fine } \\
\text { punctate (Ferrer 2000) }\end{array}$ & $\begin{array}{c}\text { No intraneuronal } \\
\text { staining (Ferrer 2000) }\end{array}$ & $\begin{array}{l}\text { Coarse dotted deposits } \\
\text { (Yang 1999) ... diffuse } \\
\text { irregular plaque-like } \\
\text { deposits, punctate } \\
\text { synaptic-like deposits, } \\
\text { aggregated granules in } \\
\text { midst of somas of } \\
\text { granular cells (Ferrer 2000) }\end{array}$ \\
\hline & MM1 & $\begin{array}{c}\text { Higher than } \\
\text { brainstem at level of } \\
\text { obex (Parchi 1996) }\end{array}$ & $\begin{array}{l}\text { Cerebellar synaptic } \\
\text { (Parchi 1999) }\end{array}$ & - & $\begin{array}{l}\text { Cerebellar synaptic } \\
\quad \text { (Parchi 1999) }\end{array}$ \\
\hline & MV1 & $\begin{array}{l}\text { Higher than } \\
\text { brainstem at level of } \\
\text { obex (Parchi 1996) }\end{array}$ & $\begin{array}{l}\text { Cerebellar synaptic } \\
\text { (Parchi 1999) }\end{array}$ & - & $\begin{array}{c}\text { Cerebellar synaptic } \\
\text { (Parchi 1999) .... } \\
\text { plaque-like deposits } \\
\text { (Parchi 1996) }\end{array}$ \\
\hline & VV1 & $\begin{array}{c}\text { Higher than } \\
\text { brainstem at level of } \\
\text { obex (Parchi 1996) }\end{array}$ & $\begin{array}{c}\text { Cerebellar synaptic } \\
\text { (Parchi 1999) ... intense } \\
\text { and widespread punctate } \\
\text { (Parchi 1996) }\end{array}$ & - & $\begin{array}{c}\text { Cerebellar synaptic } \\
\text { (Parchi 1999) ... intense } \\
\text { and widespread punctate, } \\
\text { plaque-like pattern (Parchi } \\
\text { 1996) }\end{array}$ \\
\hline & MM2 & $\begin{array}{l}\text { Less than or equal to } \\
\text { brainstem at level of } \\
\text { obex (Parchi 1996) }\end{array}$ & $\begin{array}{l}\text { Cerebellar synaptic } \\
\text { (Parchi 1999) }\end{array}$ & - & $\begin{array}{c}\text { Cerebellar synaptic } \\
\text { (Parchi 1999) ... } \\
\text { plaque-like deposits } \\
\text { (Parchi 1996) }\end{array}$ \\
\hline & MV2 & $\begin{array}{c}\text { Higher than } \\
\text { brainstem at level of } \\
\text { obex (Parchi 1996) }\end{array}$ & $\begin{array}{l}\text { Cerebellar synaptic } \\
\text { (Parchi 1999) }\end{array}$ & - & $\begin{array}{c}\text { Plaque-like (Parchi 1996) } \\
\text {... cerebellar synaptic } \\
\text { (Parchi 1999) }\end{array}$ \\
\hline & VV2 & $\begin{array}{c}\text { Higher than } \\
\text { brainstem at level of } \\
\text { obex (Parchi 1996) }\end{array}$ & $\begin{array}{c}\text { Cerebellar synaptic } \\
\text { (Parchi 1999) ....... } \\
\text { intense and widespread } \\
\text { punctate (Parchi 1996) }\end{array}$ & - & $\begin{array}{c}\text { Cerebellar synaptic } \\
\text { (Parchi 1999) ... intense } \\
\text { and widespread punctate, } \\
\text { plaque-like pattern (Parchi } \\
\text { 1996) }\end{array}$ \\
\hline iCJD & & - & Synaptic (Shijo 2017) & - & Synaptic (Shijo 2017) \\
\hline vCJD & & - & $\begin{array}{l}\text { Diffuse and florid plaques } \\
\text { (Armstrong 2009) }\end{array}$ & $\begin{array}{l}\text { No staining evident } \\
\text { (Armstrong 2009) }\end{array}$ & $\begin{array}{l}\text { Diffuse and florid plaques, } \\
\text { greater density than } \\
\text { molecular layer } \\
\text { (Armstrong 2009) }\end{array}$ \\
\hline
\end{tabular}


Table 9. Cont.

\begin{tabular}{|c|c|c|c|c|c|}
\hline Strain & Subtype & $\begin{array}{c}\text { Relative } \\
\text { Accumulation }\end{array}$ & Molecular Layer & $\begin{array}{c}\text { Purkinje Cell } \\
\text { Layer }\end{array}$ & Granule Cell Layer \\
\hline GSS & & $\begin{array}{l}\text { Lower than } \\
\text { brainstem at level of } \\
\text { obex (Bugiani 2000) }\end{array}$ & $\begin{array}{c}\text { Kuru plaques, } \\
\text { synaptic-type depositions } \\
\text { (Yang 1999) ... large } \\
\text { multicore plaques (Budka } \\
\text { 1995) ... amyloid deposits } \\
\text { (Bugiani 2000) }\end{array}$ & - & $\begin{array}{c}\text { Kuru plaques, } \\
\text { synaptic-type depositions } \\
\text { (Yang 1999) ... fewer and } \\
\text { smaller kuru plaques } \\
\text { (Budka 1995) ... amyloid } \\
\text { plaques (Bugiani 2000) }\end{array}$ \\
\hline KURU & & - & $\begin{array}{l}\text { Occasional kuru plaques } \\
\text { (Brandner 2008)... } \\
\text { synaptic type and plaque } \\
\text { deposits, florid plaques } \\
\text { (Hainfellner 1997) }\end{array}$ & $\begin{array}{l}\text { Plaques (Hainfellner } \\
\text { 1997, Bradner 2008) }\end{array}$ & $\begin{array}{l}\text { Occasional kuru plaques } \\
\text { (Brandner 2008) ... Kuru } \\
\text { plaques most numerous } \\
\text { here (Liberski 2012) ... } \\
\text { synaptic type and plaque } \\
\text { deposits, more prominent } \\
\text { than in molecular layer } \\
\text { (Hainfellner 1997) }\end{array}$ \\
\hline
\end{tabular}

(-) Not reported.

\subsection{Bovine Spongiform Encephalopathy}

There are differences in the intensity and patterns of $\mathrm{PrP}^{\mathrm{Sc}}$ accumulation in the cerebella of cattle with different strains of BSE [47,53,110,112,159,160,167-169]. A summary of these differences can be found in Table 5. In cattle with C-BSE, there is more $\mathrm{PrP}^{\mathrm{Sc}}$ deposition in the molecular layer than in the granule cell layer [53]. In the molecular layer there is prominent stellate and linear staining patterns whereas the granule cell layer is made up of fine and coarse granular to aggregated staining patterns [53] [53,167,168,170]. In relation to the brainstem at the level of the obex, the cerebellar cortices of cattle with L-BSE have significantly stronger $\mathrm{PrP}^{\mathrm{Sc}}$ signal intensities $[47,160]$ than cattle with C-BSE and H-BSE [160]. Cattle with L-BSE have an even distribution of immunoreactivity in the molecular and granule cell layers [159]. The $\mathrm{PrP}^{\mathrm{Sc}}$ accumulation in the cerebellum of cattle with L-BSE was diffuse and is a similar pattern to the accumulation observed in the cerebellar cortices of sheep with atypical scrapie [159]. Compared to cattle with L-BSE, the molecular and granule cell layers of cattle with H-BSE have substantially less $\operatorname{PrP}^{\mathrm{Sc}}$ accumulation that is less uniform [159]. Cattle with H-BSE have a stellate immunolabelling of $\mathrm{PrP}^{\mathrm{Sc}}$ with plaques in the cerebellar cortices [112] and pronounced widespread glial staining in the white matter of the cerebellum when compared to C-BSE and L-BSE counterparts [112,159]. In the E211K H-BSE, staining of the cerebellum is scant with small, multifocal clumps of $\mathrm{PrPSc}^{\mathrm{Sc}}$ in both the molecular and granule cell layers [110]. Further, there is a fine granular, particulate, and stellate immunolabelling pattern in the molecular layer with coarse granular and particulate labelling of $\mathrm{PrP}^{\mathrm{Sc}}$ in the granule cell layer [53]. Cattle with the E211K H-BSE generally do not display immunoreactivity in the cerebellar white matter, differing from cattle with $\mathrm{H}$-BSE in which the most prominent $\mathrm{PrP}^{\mathrm{Sc}}$ staining occurs in the cerebellar white matter [110,159]. In cattle with E211K H-BSE, immunolabelling against $\mathrm{PrPSC}^{\mathrm{Sc}}$ in the granule cell layer is comparable to that of C-BSE. Cattle with E211K H-BSE have fine granular and stellate labelling in the molecular layer of the cerebellum while cattle with C-BSE have prominent stellate and linear labelling in the molecular layer [53]. Little information is specifically reported on the Purkinje cells of cattle with BSE; however, published images indicate that there is little to no staining of Purkinje cells in any strain of BSE [53,159]. Overall, the greatest difference in the cerebellar cortices of cattle with different strains of BSE is L-BSE in which there is a significantly greater concentration of $\mathrm{PrPSc}^{\mathrm{Sc}}$ accumulation in relation to the brainstem at the level of the obex. These differences suggest that the cerebellum is more reliable by immunohistochemistry for differentiating between strains of BSE than the brainstem at the level of the obex in cattle with BSE [159]. 


\subsection{Scrapie}

The relative intensity and pattern of $\operatorname{PrP}^{\mathrm{Sc}}$ accumulation varies in the cerebella of sheep and goats with different strains of scrapie $[4,26,58,119,122,123,161,164,171,172]$. A summary of these differences can be found in Tables 6 and 7. Overall, $\operatorname{PrP}^{\mathrm{Sc}}$ deposition in the cerebellum (relative to the brainstem at the level of the obex in the same animal) is less intense and widespread in cases of classical scrapie compared to cases of atypical scrapie [26]. In sheep with classical scrapie, the cerebellum has strong immunoreactivity for $\mathrm{PrP}^{\mathrm{Sc}}$ that is stronger in the granule cell layer than the molecular layer [26]. The staining is multifocal in the molecular layer and white matter [26]. The Purkinje cells in sheep with classical scrapie have some intraneuronal $\mathrm{PrPSc}^{\mathrm{Sc}}$ accumulation [119]. The staining in the cerebella is genotype-dependent at codon 171 of the PRNP gene in sheep with classical scrapie [119]. Sheep with lysine at codon 171 of the PRNP gene (QK171 or KK171) had similar staining in the cerebella and was different from sheep homozygous for glutamine (QQ171) [119]. The former commonly have accumulation of misfolded prion protein in the white matter while the latter sheep lack this $\mathrm{PrP}^{\mathrm{Sc}}$ accumulation [119]. Overall, the patterns of accumulation in the granule cell and molecular layer in the cerebellar cortices in classical scrapie is not genotype-dependent at codon 171 of the PRNP gene: granular, intraneuronal, and intraglial in the granule cell layer as well as scant punctate, granular, and stellate patterns in the molecular layer [119].

In sheep with atypical scrapie, the cerebellum has intense immunoreactivity for $\mathrm{PrP}^{\mathrm{Sc}}$ that is stronger in the molecular layer than the granule cell layer $[26,58,173]$. Sheep with atypical scrapie primarily have $\mathrm{PrPSc}^{\mathrm{Sc}}$ accumulation in the cerebellar cortex $[3,4,58,161,171,173]$ while sheep with classical scrapie do not $[4,26]$. In sheep with atypical scrapie the staining patterns in the cerebellum is granular and punctate [58,173]. Cases of atypical scrapie have varied staining in the cerebellar white matter [161]. Unlike cases of classical scrapie in sheep, the Purkinje cells of those with atypical scrapie are always negative [161]. Again, atypical cases of scrapie have higher relative amounts of misfolded prion accumulation in the cerebellum in relation to their brainstem compared to the same structures in sheep with classical scrapie [58]. Still, some diversity exists in the degree of $\mathrm{PrP}^{\mathrm{Sc}}$ deposition, as it has been reported that some sheep with atypical scrapie have cerebella that are minimally affected [171]. When classical scrapie presents in goats, there is $\operatorname{PrP}^{\mathrm{Sc}}$ accumulation in the cerebellum $[122,123,164]$. Subpial immunolabelling against $\mathrm{PrP}^{\mathrm{Sc}}$ occurs in the cerebella of goats with classical scrapie [122]. Cytoplasmic staining is strong and widespread in the molecular layer, granule cell layer, Purkinje cells, and cerebellar white matter [123]. In sheep with scrapie, the cerebellum allows for differentiation between strains. While the cerebellar cortex displays $\mathrm{PrP}^{\mathrm{Sc}}$ immunoreactivity in sheep with classical and atypical strains of scrapie, it is greater in sheep with atypical scrapie in relation to $\mathrm{PrPSc}^{\mathrm{Sc}}$ accumulation in the brainstem at the level of the obex. Additionally, sheep with classical scrapie tend to accumulate more misfolded prion protein in the granule cell layer while sheep with atypical scrapie accumulate more $\mathrm{PrP}^{\mathrm{Sc}}$ in the molecular layer.

\subsection{Chronic Wasting Disease}

The misfolded prion protein deposits differentially in both intensity and pattern in the cerebella of cervids with CWD, as species and genotype both affect $\operatorname{PrP}^{\mathrm{Sc}}$ accumulation $[129,132,162,174]$. A summary of these differences can be found in Table 8 . The accumulation of misfolded prion protein differs in the cerebella of white-tailed deer based on genotype. In experimentally inoculated white-tailed deer, there are two PRNP codons associated with differences in $\mathrm{PrP}^{\mathrm{Sc}}$ accumulation. The white-tailed deer wild-type prion protein allele is Q95/G96; codon 95 can instead be histidine $(\mathrm{H})$ and codon 96 can instead be serine (S). Differences in accumulation pattern and intensity of $\mathrm{PrP}^{\mathrm{Sc}}$ will be discussed in the following order: wildtype, S96, H95, H95/S96. In wildtype white-tailed deer, there is abundant coalescing $\mathrm{PrP}^{\mathrm{Sc}}$ and plaques stretching in the granule cell layer and Purkinje cell layer. This occurs as coarse granular and large plaques [129]. In deer of the S96 genotype, accumulation of $\mathrm{PrP}^{\mathrm{Sc}}$ is confined to the granule cell layer and white matter. 
In comparison to wildtype white-tailed deer, deer of the $\mathrm{S} 96$ genotype display less intense accumulation that is granular and diffuse [129]. Even less $\mathrm{PrPSc}$ accumulation occurs in the cerebellar cortices of deer of the H95 genotype that are infected with CWD [129] with the predominance of staining in the granule cell layer and minimal labelling in the Purkinje cell and molecular layers. This accumulation of $\mathrm{PrP}^{\mathrm{Sc}}$ is discontinuous and diffuse in the granule cell layer as fine punctate and coarse small granular deposits with some plaque-like deposits [129]. When these polymorphisms are simultaneous (H95/S96), accumulation of $\mathrm{PrP}^{\mathrm{Sc}}$ manifests as fine punctate and coarse granular deposits that were evenly distributed in the granule cell layer [129]. The molecular layer of white-tailed deer with H95/S96 polymorphisms demonstrated more intense accumulation of $\mathrm{PrP}^{\mathrm{Sc}}$ than the deer of the wildtype, S96, and H95 genotypes [129]. White-tailed deer of the H95/S96 genotype displayed stellate aggregates of misfolded prion protein in the molecular layer of the cerebellar cortex [129].

In reindeer, $\mathrm{PrP}^{\mathrm{Sc}}$ accumulation ranges in intensity overall [132], but is consistently more intense in granule cell layers when compared to the molecular layer $[13,132]$ with Purkinje cells devoid of accumulation [132]. Reindeer show punctate deposits of $\mathrm{PrP}^{\mathrm{Sc}}$ throughout the cerebellar cortex in less intense cases while particulate and aggregated deposits occur in more intense cases [132]. The cerebellar cortex of Rocky Mountain elk affected by CWD has glial-associated $\mathrm{PrPSc}^{\mathrm{Sc}}$ accumulation that was granular to punctate and was most prominent in the white matter [130]. Mule deer with CWD have accumulation of $\mathrm{PrP}^{\mathrm{Sc}}$ plaques in the cerebellar cortex that are present in the granule cell layer and molecular layer [174]. While the cerebellar cortex offers discernable pathological phenotypes in white-tailed deer with CWD for potential strain differentiation, there is not enough characterization in other cervids to draw conclusions.

\subsection{Human Prion Diseases}

$\operatorname{PrP}^{\mathrm{Sc}}$ accumulates in the cerebella of humans with prion diseases [95,163,166,175-177]. A summary of these differences can be found in Table 9. The immunostaining pattern in the cerebellar cortex of people with vCJD is described as diffuse and florid plaques [175]. The density of $\mathrm{PrP}^{\mathrm{Sc}}$ accumulation was increased in the granule cell layer compared to the molecular layer of the cerebellar cortices in people with vCJD [175]. One report on an individual with dura mater-derived iCJD states that there was Type $1 \mathrm{PrP}^{\mathrm{Sc}}$ accumulated in the cerebellar cortex. A synaptic staining pattern was found in both the molecular and granule cell layer of the cerebellar cortex [177]. When $\mathrm{PrP}^{\mathrm{Sc}}$ accumulates in humans with SCJD, reports vary. Some state that people with $\mathrm{SCJD}$ accumulate $\mathrm{PrP}^{\mathrm{Sc}}$ equally in the molecular and granule cell layer of the cerebellum [178], whereas others report that coarse dotted deposits of $\mathrm{PrP}^{\mathrm{Sc}}$ accumulate in the granule cell layer and diffuse fine dotted deposits in the molecular layer $[163,179]$. There is evidence that staining patterns vary depending on the subtype of sCJD. People with either the MM1 or MV1 subtype display fine punctate deposits with diffuse aggregates that were occasionally described as coarse [85,89]. PrPSc plaques in the cerebellum of people with VV1 or MM2 subtype are rare, although more common in people of the MM2 subtype $[85,89]$. Otherwise, $\operatorname{Pr} \mathrm{PSc}^{\mathrm{Sc}}$ deposition in people of the MM2 subtype is described as coarse [85]. People with the VV2 and MV2 subtype have prominent involvement of the cerebellum $[85,89]$ with these subtypes displaying plaque-like deposits primarily in the granule cell layer [85]. The VV2 subtype does not display Kuru-like deposits while diffuse plaques and punctate deposits are common [89]. In people of the MV2 subtype, kuru-like plaques are prominent [89].

Staining patterns are clearly different between people with sCJD compared to people with GSS [163]. Patients with GSS have Kuru plaques with synaptic localization of $\operatorname{PrP}^{\mathrm{PC}}$ in both the molecular and granule cell layer [163]. Amyloid deposits of $\mathrm{PrPSc}^{\mathrm{Sc}}$ occur in both the molecular and granule cell layers of the cerebellum in people with GSS [95,153] and increased deposition occurs in the molecular layer [165]. For those with Kuru, misfolded prion protein accumulates in the cerebellum $[155,157,180]$. In the cerebellar cortices of people with Kuru, 
$\mathrm{PrP}^{\mathrm{Sc}}$ is not prominent in the molecular layer and is greater in the Purkinje cell and granule cell layer as fine granular diffuse deposits and plaques $[155,157,158]$.

\section{Enteric Nervous System}

In animals with prion diseases, $\mathrm{PrP}^{\mathrm{Sc}}$ accumulates differentially in the enteric nervous system, a division of the nervous system that spans the entire digestive tract. The differential accumulation of $\mathrm{PrP}^{\mathrm{Sc}}$ is influenced by route of infection in addition to being both strain-dependent and genotype-dependent. While the enteric nervous system has long been thought to be a portal of $\mathrm{PrPSc}^{\mathrm{Sc}}$ entry to the central nervous system, it was not definitively demonstrated until 1999 [181].

$\mathrm{PrP}^{\mathrm{Sc}}$ accumulates differentially in the enteric nervous system of animals with prion diseases and these differences may allow for greater understanding of TSE pathogenesis and strain differentiation. Accumulation is not always predictable by route of infection. Beyond strain, differences in $\mathrm{PrP}^{\mathrm{Sc}}$ accumulation in the enteric nervous system occur due to propagation differences between natural infection, experimental intracranial inoculation, and experimental oronasal inoculation. Positive accumulation in the enteric nervous system is the result of centrifugal spread throughout the host following oronasal inoculation versus centripetal spread following intracranial inoculation. For example, AA136 sheep that were oronasally inoculated with the scrapie strain $x 124$ were not susceptible to the agent and therefore did not accumulate $\mathrm{PrP}^{\mathrm{Sc}}$ in the enteric nervous system. However, AA136 sheep that were intracranially inoculated with the x124 scrapie strain were positive for $\mathrm{PrP}^{\mathrm{Sc}}$ in the enteric nervous system. The No. 13-7 scrapie strain counterparts in this study displayed different results. The No. 13-7 AA136 oronasally inoculated sheep were positive in the enteric nervous system while the intracranially inoculated AA136 sheep were negative [115]. Further, enteric nervous system accumulation did not occur following oral inoculation of atypical L-BSE although the cattle in this study was positive in other peripheral tissues [47]. Interestingly, it has also been reported that peripheral tissues accumulated $\mathrm{PrP}^{\mathrm{Sc}}$ in cattle intracranially inoculated with BSE; however, the enteric nervous system remained negative $[159,182]$. In another study, cattle orally challenged with C-BSE demonstrated $\mathrm{PrP}^{\mathrm{Sc}}$ accumulation in the enteric nervous system throughout the entire time course [183]. In addition to being strain-dependent, the accumulation of misfolded prion protein is genotype-dependent [184]. Here we summarize the differential accumulation of $\mathrm{PrP}^{\mathrm{Sc}}$ in the myenteric (Auerbach's) plexus and submucosal (Meissner's) plexus throughout the enteric nervous system in cattle with BSE, sheep and goats with scrapie, cervids with CWD, and humans with prion diseases (Tables 10-14). We will specify inoculation route throughout.

Table 10. Immunolabelling patterns of $\mathrm{PrP}^{\mathrm{Sc}}$ in the enteric nervous system in cattle with BSE.

\begin{tabular}{|c|c|c|c|c|}
\hline Strain & Genotype & ENS & Submucosal Plexus & Myenteric Plexus \\
\hline Classical & & $\begin{array}{l}\text { Positive (Balkema-Buschmann } \\
\text { 2011, Hoffmann 2011, Kaatz 2012, } \\
\text { Franz 2012) ... no } \\
\text { immunolabelling (Konold 2012, } \\
\text { Moore 2016) }\end{array}$ & $\begin{array}{l}\text { Perineuronal and an } \\
\text { association to satellite } \\
\text { cells, intraneuronal, } \\
\text { intraglial (Kaatz 2012) }\end{array}$ & $\begin{array}{c}\text { Perineuronal and an } \\
\text { association to satellite cells, } \\
\text { intraneuronal, intraglial (Kaatz } \\
\text { 2012) ... sparse } \\
\text { immmunostaining, fine } \\
\text { granular deposits (Terry 2003) }\end{array}$ \\
\hline H-type & & $\begin{array}{l}\text { No immunolabelling } \\
\text { (Konold 2012) }\end{array}$ & - & - \\
\hline H-type & E211K & $\begin{array}{c}\text { Negative (Greenlee 2012, } \\
\text { Moore 2016) }\end{array}$ & - & - \\
\hline L-type & & $\begin{array}{l}\text { Negative (Okada 2017) ... no } \\
\text { immunolabelling (Konold 2012) }\end{array}$ & - & - \\
\hline
\end{tabular}


Table 11. Immunolabelling patterns of $\mathrm{PrPSc}^{\mathrm{Sc}}$ in the enteric nervous system in sheep with naturally occurring classical scrapie.

\begin{tabular}{|c|c|c|c|}
\hline Genotype & ENS & Submucosal Plexus & Myenteric Plexus \\
\hline VRQ/VRQ & $\begin{array}{l}\text { Positive (van Keulen 1999, 2002; } \\
\text { Andreoletti 2000, Gonzalez 2014) }\end{array}$ & $\begin{array}{l}\text { Positive (van Keulen 1999, } \\
\text { 2002) ... intraneuronal } \\
\text { (Andreoletti 2000) }\end{array}$ & Positive (van Keulen 1999, 2002) \\
\hline VRQ/ARQ & $\begin{array}{l}\text { Positive (van Keulen 1999, } \\
\text { Gonzalez 2014) }\end{array}$ & - & - \\
\hline VRQ/ARH & Positive (van Keulen 1999) & - & - \\
\hline VRQ/AHQ & Positive (van Keulen 1999) & - & - \\
\hline ARQ/ARQ & $\begin{array}{c}\text { Positive (van Keulen 1999, Heggebo } \\
\text { 2003, Gonzalez 2014, Marruchella } \\
\text { 2007, Jeffrey 2006) }\end{array}$ & $\begin{array}{c}\text { Intraneuronal (Heggebo 2003, } \\
\text { Marruchella 2007) . . . } \\
\text { granular (Marruchella 2007) }\end{array}$ & $\begin{array}{c}\text { Intraneuronal (Heggebo 2003, } \\
\text { Marruchella 2007) ... granular } \\
\text { (Marruchella 2007) }\end{array}$ \\
\hline VRQ/ARR & Positive (Gonzalez 2014) & - & - \\
\hline ARQ/ARR & $\begin{array}{l}\text { Positive (Gonzalez 2014, } \\
\text { Marruchella 2007) }\end{array}$ & $\begin{array}{l}\text { Granular, intraneuronal } \\
\text { (Marruchella 2007) }\end{array}$ & $\begin{array}{l}\text { Granular, intraneuronal } \\
\text { (Marruchella 2007) }\end{array}$ \\
\hline ARR/ARR & $\begin{array}{l}\text { Positive (van Keulen 1999) ... } \\
\text { clinically normal (Andreoletti 2000, } \\
\text { Jeffrey 2006) }\end{array}$ & $\begin{array}{l}\text { Granular, intraneuronal } \\
\text { (Marruchella 2007) }\end{array}$ & $\begin{array}{l}\text { Granular, intraneuronal } \\
\text { (Marruchella 2007) }\end{array}$ \\
\hline
\end{tabular}

(-) Not reported.

Table 12. Immunolabelling patterns of $\mathrm{PrP}^{\mathrm{Sc}}$ in the enteric nervous system in sheep and goats experimentally inoculated with classical scrapie.

\begin{tabular}{|c|c|c|c|c|c|}
\hline Species & Strain & Genotype & ENS & Submucosal Plexus & Myenteric Plexus \\
\hline \multirow{9}{*}{ Sheep } & \multirow{6}{*}{ Classical (No. 13-7) } & VV136 & $\begin{array}{l}\text { Intraneuronal and } \\
\text { intraglial fine granules } \\
\text { (Moore 2016) }\end{array}$ & $\begin{array}{l}\text { Intraneuronal and } \\
\text { intraglial fine granules, } \\
\text { occassionally cell } \\
\text { membranes } \\
\text { (Moore 2016) }\end{array}$ & $\begin{array}{c}\text { Intraneuronal and } \\
\text { intraglial fine granules, } \\
\text { occasional cell membranes } \\
\text { (Moore 2016) }\end{array}$ \\
\hline & & AV136 & $\begin{array}{l}\text { Intraneuronal and } \\
\text { intraglial fine granules } \\
\text { (Moore 2016) }\end{array}$ & $\begin{array}{l}\text { Intraneuronal and } \\
\text { intraglial fine granules, } \\
\text { occassionally cell } \\
\text { membranes } \\
\text { (Moore 2016) }\end{array}$ & $\begin{array}{c}\text { Intraneuronal and } \\
\text { intraglial fine granules, } \\
\text { occasional cell membranes } \\
\text { (Moore 2016) }\end{array}$ \\
\hline & & AA136 & $\begin{array}{l}\text { Intraneuronal and } \\
\text { intraglial fine granules } \\
\text { (Moore 2016) }\end{array}$ & $\begin{array}{l}\text { Intraneuronal and } \\
\text { intraglial fine granules, } \\
\text { occassionally cell } \\
\text { membranes } \\
\text { (Moore 2016) }\end{array}$ & $\begin{array}{c}\text { Intraneuronal and } \\
\text { intraglial fine granules, } \\
\text { occasional cell membranes } \\
\text { (Moore 2016) }\end{array}$ \\
\hline & & KK171 & $\begin{array}{c}\text { Negative } \\
\text { (Cassmann 2019) }\end{array}$ & $\begin{array}{c}\text { Negative } \\
\text { (Cassmann 2019) }\end{array}$ & Negative (Cassmann 2019) \\
\hline & & QK171 & $\begin{array}{c}\text { Positive } \\
\text { (Cassmann 2019) }\end{array}$ & $\begin{array}{c}\text { Positive } \\
\text { (Cassmann 2019) }\end{array}$ & Positive (Cassmann 2019) \\
\hline & & QQ171 & $\begin{array}{c}\text { Positive } \\
\text { (Cassmann 2019) }\end{array}$ & $\begin{array}{c}\text { Positive } \\
\text { (Cassmann 2019) }\end{array}$ & Positive (Cassmann 2019) \\
\hline & \multirow[t]{3}{*}{ Classical (x124) } & VV136 & $\begin{array}{l}\text { Intraneuronal and } \\
\text { intraglial fine granules } \\
\text { (Moore 2016) }\end{array}$ & $\begin{array}{l}\text { Intraneuronal and } \\
\text { intraglial fine granules, } \\
\text { occassionally cell } \\
\text { membranes } \\
\text { (Moore 2016) }\end{array}$ & $\begin{array}{c}\text { Intraneuronal and } \\
\text { intraglial fine granules, } \\
\text { occasional cell membranes } \\
\text { (Moore 2016) }\end{array}$ \\
\hline & & AV136 & $\begin{array}{l}\text { Intraneuronal and } \\
\text { intraglial fine granules } \\
\text { (Moore 2016) }\end{array}$ & $\begin{array}{l}\text { Intraneuronal and } \\
\text { intraglial fine granules, } \\
\text { occassionally cell } \\
\text { membranes } \\
\text { (Moore 2016) }\end{array}$ & $\begin{array}{c}\text { Intraneuronal and } \\
\text { intraglial fine granules, } \\
\text { occasional cell membranes } \\
\text { (Moore 2016) }\end{array}$ \\
\hline & & AA136 & $\begin{array}{l}\text { Dependent on } \\
\text { inoculation route } \\
\left(\text { Moore } 2016^{*}\right)\end{array}$ & $\begin{array}{l}\text { Dependent on } \\
\text { inoculation route } \\
\left(\text { Moore } 2016^{*}\right)\end{array}$ & $\begin{array}{l}\text { Dependent on inoculation } \\
\text { route (Moore 2016 *) }\end{array}$ \\
\hline
\end{tabular}


Table 12. Cont.

\begin{tabular}{|c|c|c|c|c|c|}
\hline Species & Strain & Genotype & ENS & Submucosal Plexus & Myenteric Plexus \\
\hline Goat & Classical & & $\begin{array}{l}\text { Positive (Valdez 2003, } \\
\text { Mammadova 2020) }\end{array}$ & Positive (Valdez 2003) & Positive (Valdez 2003) \\
\hline
\end{tabular}

(-) Not reported. * Intranasally inoculated sheep were negative. Intracranially inoculated sheep were positive.

Table 13. Immunolabelling patterns of $\mathrm{PrP}^{\mathrm{Sc}}$ in the enteric nervous system in sheep experimentally inoculated with atypical scrapie.

\begin{tabular}{cccc}
\hline Genotype & ENS & Submucosal Plexus & Myenteric Plexus \\
\hline VRQ/ARQ & Negative (Cassmann 2021) & Negative (Cassmann 2021) & Negative (Cassmann 2021) \\
ARQ/ARQ & Negative (Cassmann 2021) & Negative (Cassmann 2021) & Negative (Cassmann 2021) \\
ARQ/ARR & Negative (Cassmann 2021) & Negative (Cassmann 2021) & Negative (Cassmann 2021) \\
AHQ/ARQ & - & - & - \\
AHQ/AHQ & - & - & - \\
ARR/ARR & - & - & - \\
\hline
\end{tabular}

(-) Not reported.

Table 14. Immunolabelling patterns of $\mathrm{PrP}^{\mathrm{Sc}}$ in the enteric nervous system in cervids with CWD.

\begin{tabular}{|c|c|c|c|c|}
\hline Species & Genotype & ENS & Submucosal Plexus & Myenteric Plexus \\
\hline \multirow[t]{2}{*}{ RME } & $132 \mathrm{MM}$ & Positive (Spraker 2009) & $\begin{array}{l}\text { On periphery of enteric } \\
\text { neurons, nonmyelinated } \\
\text { nerves located within the } \\
\text { intestinal submucosa } \\
\text { (Spraker 2009) }\end{array}$ & $\begin{array}{l}\text { Granules surrounding } \\
\text { myenteric neurons located in } \\
\text { ganglion between bundles of } \\
\text { smooth muscle (Spraker 2009) }\end{array}$ \\
\hline & 132ML & Positive (Spraker 2009) & $\begin{array}{l}\text { On periphery of enteric } \\
\text { neurons, nonmyelinated } \\
\text { nerves located within the } \\
\text { intestinal submucosa } \\
\text { (Spraker 2009) }\end{array}$ & $\begin{array}{l}\text { Granules surrounding } \\
\text { myenteric neurons located in } \\
\text { ganglion between bundles of } \\
\text { smooth muscle (Spraker 2009) }\end{array}$ \\
\hline \multirow[t]{2}{*}{ RD } & 132LL & $\begin{array}{c}- \\
\text { Prominent (Mitchell 2012) }\end{array}$ & Granular (Mitchell 2012) & $\begin{array}{c}- \\
\text { Granular (Mitchell 2012) }\end{array}$ \\
\hline & Q95/G96 & $\begin{array}{l}\text { Positive (Otero 2019, } \\
\text { Mammadova 2020) }\end{array}$ & - & - \\
\hline \multirow{3}{*}{ WTD } & Q95/S96 & $\begin{array}{l}\text { Positive (Otero 2019, } \\
\text { Mammadova 2020) }\end{array}$ & - & - \\
\hline & H95/G96 & Positive (Otero 2019) & - & - \\
\hline & $\mathrm{H} 95 / \mathrm{S} 96$ & Positive (Otero 2019) & - & - \\
\hline MD & & $\begin{array}{l}\text { Not found (Spraker 2002) } \\
\text {.. positive, coarse } \\
\text { (Sigurdson 2001) }\end{array}$ & - & $\begin{array}{l}\text { Not found (Spraker 2002) ... } \\
\text { positive, coarse stain, in } \\
\text { myenteric ganglion cell bodies, } \\
\text { along nerve fibers and in } \\
\text { satellite cells (Sigurdson 2001) }\end{array}$ \\
\hline
\end{tabular}

(-) Not reported.

\subsection{Bovine Spongiform Encephalopathy}

$\operatorname{PrP}^{\mathrm{Sc}}$ accumulates in the myenteric plexus and submucosal plexus of the enteric nervous system in cattle with C-BSE following oral inoculation and subsequent $\operatorname{Pr} \mathrm{PSc}^{\mathrm{Sc}}$ uptake [183,185-188]. A summary of these differences can be found in Table 10. The staining pattern following oral inoculation in the myenteric and submucosal plexuses was not clustered and localized to positive lymph follicles. In these cases, it was suggested that this could be due to direct neuroinvasion that evades gut-associated lymphoid tissue following oral inoculation [186]. The earliest $\mathrm{PrP}^{\mathrm{Sc}}$ accumulation is observed in the myenteric plexus of cattle with C-BSE is at 16 months post-inoculation in the ileum during preclinical stages [186]. Immunolabelling against $\mathrm{PrP}^{\mathrm{Sc}}$ is observed to have limited involvement that lasts until clinical stages of the disease following oral inoculation; however, distribution of 
$\mathrm{PrP}^{\mathrm{Sc}}$ in the enteric nervous system was wider in cattle with longer incubation periods [186]. Intense staining occurs at end stages of C-BSE in orally inoculated cattle that manifests as linear, intraglial, intraneuronal, and perineuronal with an association to the satellite cell in the myenteric and submucosal plexuses of the enteric nervous system $[183,186]$. There was no obvious association between immunolabelling against $\mathrm{PrP}^{\mathrm{Sc}}$ in the enteric nervous system and positive Peyer's patch follicles $[183,186]$. H-BSE and L-BSE showed no enteric nervous system involvement, even following the successful oral transmission of atypical BSE [47,159]. Immunohistochemistry failed to demonstrate the presence of $\mathrm{PrPSc}^{\mathrm{Sc}}$ accumulation in the enteric nervous system of cattle with E211K H-BSE following intracranial inoculation $[53,110]$.

\subsection{Scrapie}

$\mathrm{PrP}^{\mathrm{Sc}}$ accumulates differentially in the enteric nervous system of sheep with classical scrapie [181,189-192], though this is not the case in sheep with atypical scrapie, as these sheep have no $\mathrm{PrPSc}^{\mathrm{Sc}}$ immunoreactivity outside the central nervous system [58]. A summary of these differences can be found in Tables 11-13. Studies often report the genotype of sheep as a sequence of three one-letter amino acid codes at codons 136, 154, and 171 of the PRNP gene that are of interest due to their influence on susceptibility to scrapie. This section reports genotypes in such a manner.

The distribution and intensity increase as classical scrapie progresses until the entire enteric nervous system has abundant $\mathrm{PrP}^{\mathrm{Sc}}$ deposition in clinical stages [189]. In sheep with classical scrapie, intraneuronal fine granules of $\operatorname{PrP}^{\mathrm{Sc}}$ deposit in the myenteric and submucosal plexuses [181]. Sheep expressing VRQ/VRQ at codons 136, 154, and 171 of the PRNP gene displayed more extensive $\mathrm{PrP}^{\mathrm{Sc}}$ accumulation in the enteric nervous system than less susceptible sheep. Sheep that expressed VRQ/VRQ were positive in all gastrointestinal sites while sheep that expressed VRQ/ARQ only showed $\operatorname{PrP}^{\mathrm{Sc}}$ accumulation from the forestomaches to the rectum; sheep that were ARQ/ARQ had $\operatorname{Pr} \mathrm{PSc}^{S \mathrm{c}}$ accumulation in the enteric nervous system of the omasum, abomasum, and intestines (sans esophagus, reticulum or rumen) [181]. The earliest detection of $\mathrm{PrP}^{\mathrm{Sc}}$ accumulation in sheep with classical scrapie is at 5 months post inoculation [191]. Sheep with classical scrapie display strong intraneuronal labelling of the ganglion and satellite cells in both myenteric and submucosal plexuses along the large and small intestines [192]. A sparse amount of neurons in the abomasum and duodenum of sheep with classical scrapie had misfolded prion protein accumulation [192]. Unlike cattle, the deposition of $\mathrm{PrP}^{\mathrm{Sc}}$ in the enteric nervous system of sheep with classical scrapie parallels the extent of deposition in the lymphoreticular system of the gut. Intraneuronal $\mathrm{PrPSc}^{\mathrm{Sc}}$ was not in enteric ganglia of forestomaches [192]. $\mathrm{PrP}^{\mathrm{Sc}}$ accumulation in classical scrapie is genotype-dependent, as enteric neuron staining did not occur in ARR/ARR or ARR/ARQ sheep [192]. This disease-specific intraneuronal immunolabelling of $\mathrm{PrP}^{\mathrm{Sc}}$ did not occur in the ganglia of the enteric nervous system in the forestomaches of sheep with classical scrapie [192]. With a sensitive protocol, $\mathrm{PrP}^{\mathrm{Sc}}$ deposition was shown to occur in the ganglia of the myenteric plexus and submucosal plexus in addition to nerve fibers in the submucosa [192]. $\mathrm{PrP}^{\mathrm{Sc}}$ deposition did not occur in the enteric nervous system near lymphoid nodules associated with inflammatory foci [192] nor was observed in the myenteric plexus at sites apart from large lymphoid aggerates in the jejunum and ileum during points in the incubation period [190]. In the forestomaches of sheep naturally infected with classical scrapie following natural infection, the enteric nervous system of the abomasum is first positive in sheep 9 months old, in which $\mathrm{PrP}^{\mathrm{Sc}}$ accumulation is present in the autonomous myenteric nervous system (and central nervous system) [190]. This study reports localization near Peyer's patches [190]. Misfolded prion protein accumulates first in the ileum before progressively spreading to adjacent tissues [190]. In this time course study following natural infection, the most severe case at 9 months of age displayed differential accumulation of $\mathrm{PrP}^{\mathrm{Sc}}$ in the autonomic myenteric nervous plexus with concomitant accumulation in the medulla oblongata at the level of the obex, specifically in the parasympathetic nucleus of the vagus nerve, that match staining in 
clinical adult controls [190]. Accumulation of the misfolded prion protein in the autonomic myenteric plexus occurred following its deposition in lymphoid tissues [190].

Genotype affects susceptibility to scrapie infection; therefore, there is no $\mathrm{PrPSc}$ accumulation in the enteric nervous system of sheep with resistant genotypes (ARK/ARK and $A R Q / A R Q)$. For example, intracranially inoculated sheep homozygous for lysine at codon 171 of the PRNP gene (ARK/ARK) are negative for $\mathrm{PrP}^{\mathrm{Sc}}$ in the enteric nervous system, while those with glutamine (ARQ/ARK or ARQ/ARQ) are positive [119]. Additional support for genotype dependence occurs in a study comparing two classical scrapie strains: No. 13-7 and x124 after intracranial (IC) or intranasal (IN) inoculation [115]. Accumulation in sheep with No. 13-7 compared to $x 124$ classical scrapie is both strain-dependent and genotype-dependent in the enteric nervous system. $\mathrm{PrP}^{\mathrm{Sc}}$ accumulates readily in all genotypes inoculated with No. 13-7, whereas accumulation is less so in sheep with x124 [115]. In sheep with x124 classical scrapie, the most susceptible sheep (VRQ/VRQ) were positive for $\mathrm{PrP}^{\mathrm{Sc}}$ while the least susceptible (ARQ/ARQ) were negative [115]. Of note, the enteric nervous system was positive in intracranially inoculated sheep with $\mathrm{ARQ} / \mathrm{ARQ}$ genotype [115]. $\mathrm{PrP}^{\mathrm{Sc}}$ displayed as fine granules intraneuronally in enteric neurons and glial cells of sheep with classical scrapie as well as the cell membranes of neurons of both the myenteric and submucosal plexuses [115]. Immunolabelling of the foregut varied by strain and genotype [115]. The enteric nervous system of the reticulum had $\operatorname{PrP}^{\mathrm{Sc}}$ deposits (13-7 IC ARQ/ARQ), rumen and abomasum (13-7 IN VRQ/VRQ), and omasum (x124 IN VRQ/VRQ, 13-7 IN ARQ/VRQ) [115]. The PrPSc deposition varied in the enteric nervous system of the jejunum, ileum, and cecum [115]. Immunolabelling in the enteric nervous system occurs at the same time as gut-associated lymphoid tissue in sheep with No. 13-7 classical scrapie, whereas concurrent accumulation in sheep with x124 only occurred in VRQ/VRQ sheep [115]. Interestingly, the enteric nervous system did not show $\mathrm{PrP}^{\mathrm{Sc}}$ accumulation in ARQ/ARQ sheep with oronasally inoculated x124, who were not susceptible to scrapie, while it was positive in ARQ/ARQ sheep with intracranially inoculated x124 [115].

The onset of $\operatorname{PrP}^{\mathrm{Sc}}$ accumulation in the enteric nervous system is genotype dependent in sheep with classical scrapie [184]. Sheep expressing VRQ/VRQ in the PRNP gene the enteric nervous system was positive in all sheep at $112 \mathrm{dpi}$ [184]. The following is a list of genotypes in increasing dpi at onset of $\mathrm{PrP}^{\mathrm{Sc}}$ accumulation in the enteric nervous system in sheep with classical scrapie: VRQ/ARQ (177 dpi), ARQ/ARQ (220 dpi), VRQ/ARR (366 dpi) [184]. The longest time period it took for any sheep in a genotype cohort to present with $\mathrm{PrP}^{\mathrm{Sc}}$ in the enteric nervous system was 2252 dpi in sheep that are ARQ/ARR [184]. Overall, this indicates that sheep more susceptible genotypes accumulate $\mathrm{PrP}^{\mathrm{Sc}}$ earlier in the enteric nervous system than more resistant sheep [184].

Further, intraneuronal accumulation occurred in enteric glial cells [193]. Sheep homozygous for ARR/ARR one month following inoculation with classical scrapie did not show $\mathrm{PrP}^{\mathrm{Sc}}$ accumulation and other sheep in this cohort remained heathy at 1.5 years following inoculation [194]. Sheep with clinical classical scrapie displayed widespread $\mathrm{PrP}^{\mathrm{Sc}}$ deposition in the enteric nervous system [194]. In this study, only sheep with clinical scrapie had $\mathrm{PrP}^{\mathrm{Sc}}$ accumulation in the enteric nervous system while this did not occur in sheep at earlier time points. Some studies suggest that amplification in the lymphoreticular system occurs prior to accumulation of $\mathrm{PrPSc}^{\mathrm{Sc}}$ in the enteric nervous system of sheep with classical scrapie $[189,191]$ while others suggest simultaneous exposure to infection [194]. In sheep with atypical scrapie, there is no deposition of $\mathrm{PrP}^{\mathrm{Sc}}$ in the enteric nervous system regardless of genotype [58,195]. In other reports of atypical scrapie in sheep, involvement of the enteric nervous system was not investigated [3,196]. In goats with classical scrapie, $\mathrm{PrP} \mathrm{PS}^{\mathrm{Sc}}$ is reported in the myenteric and submucosal plexuses of the enteric nervous system $[122,123]$. 


\subsection{Chronic Wasting Disease}

$\mathrm{PrP}^{\mathrm{Sc}}$ accumulates in the myenteric and submucosal plexuses of the enteric nervous system in cervids with CWD $[129,131,133,197,198]$. A summary of these differences can be found in Table 14. In white-tailed deer that were orally inoculated with CWD, $\mathrm{PrP}^{\mathrm{Sc}}$ accumulation occurred in the nerve fibers and ganglia of the enteric nervous system throughout the intestine [129]. Distribution of $\mathrm{PrP}^{\mathrm{Sc}}$ accumulation was genotype-dependent in whitetailed deer with CWD [129]. White-tailed deer with the genotypes H95/G96 or H95/S96 had less $\mathrm{PrP}^{\mathrm{Sc}}$ accumulation in the villi and crypts of the intestinal mucosa than whitetailed deer with the genotypes Q95/G96 or Q95/S96 deer [129]. This difference happened to the greatest degree at the ileocecal junction, as Q95/G96 and Q95/S96 white-tailed deer displayed strong $\mathrm{PrP}^{\mathrm{Sc}}$ accumulation, whereas H95/G96 and H95/S96 deer showed no $\mathrm{PrP}^{\mathrm{Sc}}$ accumulation [129]. In Rocky Mountain elk naturally infected with CWD, $\mathrm{PrP} \mathrm{Pc}^{\mathrm{Sc}}$ accumulation in the enteric nervous system was evident in the myenteric and submucosal plexuses [197]. In reindeer orally inoculated with CWD, $\mathrm{PrP}^{\mathrm{Sc}}$ accumulation is prominent in the myenteric and submucosal plexuses throughout the intestines [131]. In mule deer with CWD, reports vary and are limited. One report states that $\mathrm{PrP}^{\mathrm{Sc}}$ accumulation did not occur in the myenteric plexus following natural infection [121], while another report on $\mathrm{PrP}^{\mathrm{Sc}}$ in the enteric nervous system of mule deer states it is positive following natural infection [198].

\subsection{Human Prion Diseases}

There is evidence of expression of $\operatorname{PrP}^{\mathrm{C}}$ in the human enteric system [199]. However, there is no data to support $\mathrm{PrP}^{\mathrm{Sc}}$ accumulation in the enteric nervous system in people with CJD or GSS [200]. In a largescale survey of appendectomies in Britain, misfolded prion protein was found to be in the appendix of individuals, a handful of cases resulted in positive immunolabelling for $\mathrm{PrP}^{\mathrm{Sc}}$ in the appendix [201]. As the appendix in humans contains enteric neural tissue [202], future studies are necessary to investigate and characterize potential $\mathrm{PrP}^{\mathrm{Sc}}$ accumulation in the enteric nervous system of people with vCJD. $\mathrm{PrP}^{\mathrm{Sc}}$ accumulation is not investigated in cases of Kuru.

\section{Conclusions}

This review focused on three regions of the nervous system where neuroinvasion and subsequent $\mathrm{PrP}^{\mathrm{Sc}}$ accumulation is often different, in different strains of TSE within a given species. The retinal ganglion cells of the retina, the cerebellar cortex, and the enteric neurons of the foregut are three regions that may be useful to examine as additional TSE strains emerge and are needed to be characterized in the natural host.

Author Contributions: Conceptualization, Z.J.L., J.J.G. and M.H.W.G.; validation, J.J.G., E.D.C. and M.H.W.G.; investigation, Z.J.L.; resources, J.J.G.; writing-original draft preparation, Z.J.L. and M.H.W.G.; writing-review and editing, Z.J.L., J.J.G., E.D.C. and M.H.W.G.; visualization, Z.J.L.; supervision, M.H.W.G.; project administration, M.H.W.G.; funding acquisition, J.J.G. All authors have read and agreed to the published version of the manuscript.

Funding: This research was funded in its entirety by congressionally appropriated funds to the United States Department of Agriculture, Agricultural Research Service. The funders of the work did not influence study design, data collection and analysis, decision to publish, or preparation of the manuscript. This research was supported in part by an appointment to the Agricultural Research Service (ARS) Research Participation Program administered by the Oak Ridge Institute for Science and Education (ORISE) through an interagency agreement between the U.S. Department of Energy (DOE) and the U.S. Department of Agriculture (USDA). ORISE is managed by ORAU under DOE contract number DE-SC0014664. All opinions expressed in this paper are the author's and do not necessarily reflect the policies and views of USDA, ARS, DOE, or ORAU/ORISE.

Data Availability Statement: Not applicable.

Acknowledgments: The authors thank Irah Dhaseleer and Jamie Hefley for their illustrations of the retina, cerebellar cortex, and enteric nervous system in Figure 1. 
Conflicts of Interest: The authors declare no conflict of interest.

\section{References}

1. Prusiner, S.B. Molecular biology of prion diseases. Science 1991, 252, 1515-1522. [CrossRef] [PubMed]

2. Brown, P.; Cathala, F.; Castaigne, P.; Gajdusek, D.C. Creutzfeldt-Jakob disease: Clinical analysis of a consecutive series of 230 neuropathologically verified cases. Ann. Neurol. 1986, 20, 597-602. [CrossRef]

3. Benestad, S.L.; Sarradin, P.; Thu, B.; Schönheit, J.; Tranulis, M.A.; Bratberg, B. Cases of scrapie with unusual features in Norway and designation of a new type, Nor98. Vet. Rec. 2003, 153, 202-208. [CrossRef]

4. Benestad, S.L.; Arsac, J.N.; Goldmann, W.; Nöremark, M. Atypical/Nor98 scrapie: Properties of the agent, genetics, and epidemiology. Vet. Res. 2008, 39, 19. [CrossRef]

5. Schneider, K.; Fangerau, H.; Michaelsen, B.; Raab, W.H. The early history of the transmissible spongiform encephalopathies exemplified by scrapie. Brain Res. Bull. 2008, 77, 343-355. [CrossRef] [PubMed]

6. Fast, C.; Groschup, M.H. Classical and Atypical Scrapie in Sheep and Goats. In Prions and Diseases; Zou, W.Q., Gambetti, P., Eds.; Springer: New York, NY, USA, 2013.

7. Eckroade, R.J.; ZuRhein, G.M.; Hanson, R.P. Transmissible mink encephalopathy in carnivores: Clinical, light and electron microscopic studies in raccons, skunks and ferrets. J. Wildl. Dis. 1973, 9, 229-240. [CrossRef] [PubMed]

8. Hope, J.; Reekie, L.J.; Hunter, N.; Multhaup, G.; Beyreuther, K.; White, H.; Scott, A.C.; Stack, M.J.; Dawson, M.; Wells, G.A. Fibrils from brains of cows with new cattle disease contain scrapie-associated protein. Nature 1988, 336, 390-392. [CrossRef]

9. Williams, E.S. Chronic wasting disease. Vet. Pathol. 2005, 42, 530-549. [CrossRef]

10. Williams, E.S.; Young, S. Spongiform encephalopathy of Rocky Mountain elk. J. Wildl. Dis. 1982, 18, 465-471. [CrossRef]

11. Babelhadj, B.; Di Bari, M.A.; Pirisinu, L.; Chiappini, B.; Gaouar, S.B.S.; Riccardi, G.; Marcon, S.; Agrimi, U.; Nonno, R.; Vaccari, G. Prion Disease in Dromedary Camels, Algeria. Emerg. Infect. Dis. 2018, 24, 1029-1036. [CrossRef]

12. Baeten, L.A.; Powers, B.E.; Jewell, J.E.; Spraker, T.R.; Miller, M.W. A natural case of chronic wasting disease in a free-ranging moose (Alces alces shirasi). J. Wildl. Dis. 2007, 43, 309-314. [CrossRef]

13. Benestad, S.L.; Mitchell, G.; Simmons, M.; Ytrehus, B.; Vikøren, T. First case of chronic wasting disease in Europe in a Norwegian free-ranging reindeer. Vet. Res. 2016, 47, 88. [CrossRef]

14. Martin, S.; Jeffrey, M.; González, L.; Sisó, S.; Reid, H.W.; Steele, P.; Dagleish, M.P.; Stack, M.J.; Chaplin, M.J.; Balachandran, A. Immunohistochemical and biochemical characteristics of BSE and CWD in experimentally infected European red deer (Cervus elaphus elaphus). BMC Vet. Res. 2009, 5, 26. [CrossRef]

15. Sohn, H.J.; Mitchell, G.; Lee, Y.H.; Kim, H.J.; Park, K.J.; Staskevicus, A.; Walther, I.; Soutyrine, A.; Balachandran, A. Experimental oral transmission of chronic wasting disease to sika deer (Cervus nippon). Prion 2020, 14, 271-277. [CrossRef]

16. Pearson, G.R.; Wyatt, J.M.; Gruffydd-Jones, T.J.; Hope, J.; Chong, A.; Higgins, R.J.; Scott, A.C.; Wells, G.A. Feline spongiform encephalopathy: Fibril and PrP studies. Vet. Rec. 1992, 131, 307-310. [CrossRef]

17. Bons, N.; Mestre-Frances, N.; Guiraud, I.; Charnay, Y. Prion immunoreactivity in brain, tonsil, gastrointestinal epithelial cells, and blood and lymph vessels in lemurian zoo primates with spongiform encephalopathy. C R Acad. Sci. III 1997, 320, 971-979. [CrossRef]

18. Sigurdson, C.J.; Miller, M.W. Other animal prion diseases. Br. Med. Bull. 2003, 66, 199-212. [CrossRef] [PubMed]

19. Béringue, V.; Vilotte, J.L.; Laude, H. Prion agent diversity and species barrier. Vet. Res. 2008, 39, 47. [CrossRef] [PubMed]

20. Fraser, H.; Dickinson, A.G. The sequential development of the brain lesion of scrapie in three strains of mice. J. Comp. Pathol. 1968, 78, 301-311. [CrossRef]

21. Pattison, I.H.; Millson, G.C. Scrapie produced experimentally in goats with special reference to the clinical syndrome. J. Comp. Pathol. 1961, 71, 101-109. [CrossRef]

22. Bruce, M.E.; McBride, P.A.; Farquhar, C.F. Precise targeting of the pathology of the sialoglycoprotein, PrP, and vacuolar degeneration in mouse scrapie. Neurosci. Lett. 1989, 102, 1-6. [CrossRef]

23. González, L.; Martin, S.; Begara-McGorum, I.; Hunter, N.; Houston, F.; Simmons, M.; Jeffrey, M. Effects of agent strain and host genotype on PrP accumulation in the brain of sheep naturally and experimentally affected with scrapie. J. Comp. Pathol. 2002, 126, 17-29. [CrossRef]

24. Safar, J.; Wille, H.; Itri, V.; Groth, D.; Serban, H.; Torchia, M.; Cohen, F.E.; Prusiner, S.B. Eight prion strains have PrP(Sc) molecules with different conformations. Nat. Med. 1998, 4, 1157-1165. [CrossRef]

25. Bessen, R.A.; Marsh, R.F. Biochemical and physical properties of the prion protein from two strains of the transmissible mink encephalopathy agent. J. Virol. 1992, 66, 2096-2101. [CrossRef]

26. Greenlee, J.J. Review: Update on Classical and Atypical Scrapie in Sheep and Goats. Vet. Pathol. 2019, 56, 6-16. [CrossRef]

27. Lühken, G.; Buschmann, A.; Brandt, H.; Eiden, M.; Groschup, M.H.; Erhardt, G. Epidemiological and genetical differences between classical and atypical scrapie cases. Vet. Res. 2007, 38, 65-80. [CrossRef]

28. Fraser, H.; Dickinson, A.G. Distribution of experimentally induced scrapie lesions in the brain. Nature 1967, $216,1310-1311$. [CrossRef] [PubMed]

29. Greenlee, J.J.; Greenlee, M.H. The transmissible spongiform encephalopathies of livestock. ILAR J. 2015, 56, 7-25. [CrossRef] [PubMed] 
30. Kovacs, G.G.; Makarava, N.; Savtchenko, R.; Baskakov, I.V. Atypical and classical forms of the disease-associated state of the prion protein exhibit distinct neuronal tropism, deposition patterns, and lesion profiles. Am. J. Pathol. 2013, 183, 1539-1547. [CrossRef]

31. Moore, J.; Tatum, T.; Hwang, S.; Vrentas, C.; West Greenlee, M.H.; Kong, Q.; Nicholson, E.; Greenlee, J. Novel Strain of the Chronic Wasting Disease Agent Isolated From Experimentally Inoculated Elk With LL132 Prion Protein. Sci. Rep. 2020, 10, 3148. [CrossRef] [PubMed]

32. Beck, K.E.; Vickery, C.M.; Lockey, R.; Holder, T.; Thorne, L.; Terry, L.A.; Denyer, M.; Webb, P.; Simmons, M.M.; Spiropoulos, J. The interpretation of disease phenotypes to identify TSE strains following murine bioassay: Characterisation of classical scrapie. Vet. Res. 2012, 43, 77. [CrossRef] [PubMed]

33. Groschup, M.H.; Buschmann, A. Rodent models for prion diseases. Vet. Res. 2008, 39, 32. [CrossRef]

34. Shikiya, R.A.; Langenfeld, K.A.; Eckland, T.E.; Trinh, J.; Holec, S.A.M.; Mathiason, C.K.; Kincaid, A.E.; Bartz, J.C. PrPSc formation and clearance as determinants of prion tropism. PLoS Pathog. 2017, 13, e1006298. [CrossRef]

35. Makarava, N.; Chang, J.C.; Molesworth, K.; Baskakov, I.V. Region-specific glial homeostatic signature in prion diseases is replaced by a uniform neuroinflammation signature, common for brain regions and prion strains with different cell tropism. Neurobiol. Dis. 2020, 137, 104783. [CrossRef]

36. Béringue, V.; Tixador, P.; Andréoletti, O.; Reine, F.; Castille, J.; Laï, T.L.; Le Dur, A.; Laisné, A.; Herzog, L.; Passet, B.; et al. Host prion protein expression levels impact prion tropism for the spleen. PLoS Pathog. 2020, 16, e1008283. [CrossRef] [PubMed]

37. Wells, G.A.; Scott, A.C.; Johnson, C.T.; Gunning, R.F.; Hancock, R.D.; Jeffrey, M.; Dawson, M.; Bradley, R. A novel progressive spongiform encephalopathy in cattle. Vet. Rec. 1987, 121, 419-420. [CrossRef]

38. Richt, J.A.; Kunkle, R.A.; Alt, D.; Nicholson, E.M.; Hamir, A.N.; Czub, S.; Kluge, J.; Davis, A.J.; Hall, S.M. Identification and characterization of two bovine spongiform encephalopathy cases diagnosed in the United States. J. Vet. Diagn. Investig. 2007, 19, 142-154. [CrossRef]

39. Foster, J.D.; Parnham, D.; Chong, A.; Goldmann, W.; Hunter, N. Clinical signs, histopathology and genetics of experimental transmission of BSE and natural scrapie to sheep and goats. Vet. Rec. 2001, 148, 165-171. [CrossRef]

40. Will, R.G.; Ironside, J.W.; Zeidler, M.; Cousens, S.N.; Estibeiro, K.; Alperovitch, A.; Poser, S.; Pocchiari, M.; Hofman, A.; Smith, P.G. A new variant of Creutzfeldt-Jakob disease in the UK. Lancet 1996, 347, 921-925. [CrossRef]

41. Collinge, J.; Sidle, K.C.; Meads, J.; Ironside, J.; Hill, A.F. Molecular analysis of prion strain variation and the aetiology of 'new variant' CJD. Nature 1996, 383, 685-690. [CrossRef]

42. Donnelly, C.A.; Ferguson, N.M.; Ghani, A.C.; Anderson, R.M. Implications of BSE infection screening data for the scale of the British BSE epidemic and current European infection levels. Proc. Biol. Sci. 2002, 269, 2179-2190. [CrossRef]

43. Arnold, M.E.; Wilesmith, J.W. Estimation of the age-dependent risk of infection to BSE of dairy cattle in Great Britain. Prev. Vet. Med. 2004, 66, 35-47. [CrossRef] [PubMed]

44. Creutzfeldt-Jakob Disease International Surveillance Network. Available online: https://www.eurocjd.ed.ac.uk/data_tables (accessed on 5 October 2021).

45. Nicholson, E.M.; Brunelle, B.W.; Richt, J.A.; Kehrli, M.E.; Greenlee, J.J. Identification of a heritable polymorphism in bovine PRNP associated with genetic transmissible spongiform encephalopathy: Evidence of heritable BSE. PLoS ONE 2008, 3, e2912. [CrossRef] [PubMed]

46. Tranulis, M.A.; Benestad, S.L.; Baron, T.; Kretzschmar, H. Atypical prion diseases in humans and animals. Top. Curr. Chem. 2011, 305, 23-50. [CrossRef] [PubMed]

47. Okada, H.; Iwamaru, Y.; Imamura, M.; Miyazawa, K.; Matsuura, Y.; Masujin, K.; Murayama, Y.; Yokoyama, T. Oral Transmission of L-Type Bovine Spongiform Encephalopathy Agent among Cattle. Emerg. Infect. Dis. 2017, 23, 284-287. [CrossRef]

48. Wadsworth, J.D.; Joiner, S.; Linehan, J.M.; Balkema-Buschmann, A.; Spiropoulos, J.; Simmons, M.M.; Griffiths, P.C.; Groschup, M.H.; Hope, J.; Brandner, S.; et al. Atypical scrapie prions from sheep and lack of disease in transgenic mice overexpressing human prion protein. Emerg. Infect. Dis. 2013, 19, 1731-1739. [CrossRef]

49. Béringue, V.; Herzog, L.; Reine, F.; Le Dur, A.; Casalone, C.; Vilotte, J.L.; Laude, H. Transmission of atypical bovine prions to mice transgenic for human prion protein. Emerg. Infect. Dis. 2008, 14, 1898-1901. [CrossRef]

50. Espinosa, J.C.; Morales, M.; Castilla, J.; Rogers, M.; Torres, J.M. Progression of prion infectivity in asymptomatic cattle after oral bovine spongiform encephalopathy challenge. J. Gen. Virol. 2007, 88, 1379-1383. [CrossRef] [PubMed]

51. Wells, G.A.; Spiropoulos, J.; Hawkins, S.A.; Ryder, S.J. Pathogenesis of experimental bovine spongiform encephalopathy: Preclinical infectivity in tonsil and observations on the distribution of lingual tonsil in slaughtered cattle. Vet. Rec. 2005, 156, 401-407. [CrossRef] [PubMed]

52. Mammadova, N.; West Greenlee, M.H.; Moore, S.J.; Sakaguchi, D.S.; Greenlee, J.J. Experimental Study Using Multiple Strains of Prion Disease in Cattle Reveals an Inverse Relationship between Incubation Time and Misfolded Prion Accumulation, Neuroinflammation, and Autophagy. Am. J. Pathol. 2020, 190, 1461-1473. [CrossRef]

53. Moore, S.J.; West Greenlee, M.H.; Smith, J.D.; Vrentas, C.E.; Nicholson, E.M.; Greenlee, J.J. A Comparison of Classical and H-Type Bovine Spongiform Encephalopathy Associated with E211K Prion Protein Polymorphism in Wild-Type and EK211 Cattle Following Intracranial Inoculation. Front. Vet. Sci. 2016, 3, 78. [CrossRef]

54. Goldmann, W. Classic and atypical scrapie-A genetic perspective. Handb. Clin. Neurol. 2018, 153, 111-120. [CrossRef] [PubMed]

55. Aguzzi, A.; Heppner, F.L.; Westner, I.M.; Glatzel, M. Prion Diseases. In Neurobiology of Disease; Gilman, S., Ed.; Academic Press: Cambridge, MA, USA, 2007; pp. 473-483. 
56. Press, C.M.; Heggebø, R.; Espenes, A. Involvement of gut-associated lymphoid tissue of ruminants in the spread of transmissible spongiform encephalopathies. Adv. Drug Deliv. Rev. 2004, 56, 885-899. [CrossRef] [PubMed]

57. St Rose, S.G.; Hunter, N.; Matthews, L.; Foster, J.D.; Chase-Topping, M.E.; Kruuk, L.E.; Shaw, D.J.; Rhind, S.M.; Will, R.G.; Woolhouse, M.E. Comparative evidence for a link between Peyer's patch development and susceptibility to transmissible spongiform encephalopathies. BMC Infect. Dis. 2006, 6, 5. [CrossRef] [PubMed]

58. Cassmann, E.D.; Mammadova, N.; Moore, S.J.; Benestad, S.; Greenlee, J.J. Transmission of the atypical/Nor98 scrapie agent to Suffolk sheep with VRQ/ARQ, ARQ/ARQ, and ARQ/ARR genotypes. PLoS ONE 2021, 16, e0246503. [CrossRef]

59. Cassmann, E.D.; Greenlee, J.J. Pathogenesis, detection, and control of scrapie in sheep. Am. J. Vet. Res. 2020, 81, 600-614. [CrossRef]

60. Will, R.G.; Alperovitch, A.; Poser, S.; Pocchiari, M.; Hofman, A.; Mitrova, E.; de Silva, R.; D'Alessandro, M.; Delasnerie-Laupretre, N.; Zerr, I.; et al. Descriptive epidemiology of Creutzfeldt-Jakob disease in six European countries, 1993-1995. EU Collaborative Study Group for CJD. Ann. Neurol. 1998, 43, 763-767. [CrossRef]

61. Cassard, H.; Torres, J.M.; Lacroux, C.; Douet, J.Y.; Benestad, S.L.; Lantier, F.; Lugan, S.; Lantier, I.; Costes, P.; Aron, N.; et al. Evidence for zoonotic potential of ovine scrapie prions. Nat. Commun. 2014, 5, 5821. [CrossRef]

62. Comoy, E.E.; Mikol, J.; Luccantoni-Freire, S.; Correia, E.; Lescoutra-Etchegaray, N.; Durand, V.; Dehen, C.; Andreoletti, O.; Casalone, C.; Richt, J.A.; et al. Transmission of scrapie prions to primate after an extended silent incubation period. Sci. Rep. 2015, 5, 11573. [CrossRef]

63. Williams, E.S.; Miller, M.W. Chronic wasting disease in deer and elk in North America. Rev. Sci. Tech. 2002, 21, 305-316. [CrossRef]

64. Williams, E.S.; Young, S. Chronic wasting disease of captive mule deer: A spongiform encephalopathy. J. Wildl. Dis. 1980, 16, 89-98. [CrossRef] [PubMed]

65. Pirisinu, L.; Tran, L.; Chiappini, B.; Vanni, I.; Di Bari, M.A.; Vaccari, G.; Vikøren, T.; Madslien, K.I.; Våge, J.; Spraker, T.; et al. Novel Type of Chronic Wasting Disease Detected in Moose (Alces alces), Norway. Emerg. Infect. Dis. 2018, 24, 2210-2218. [CrossRef]

66. Nonno, R.; Di Bari, M.A.; Pirisinu, L.; D’Agostino, C.; Vanni, I.; Chiappini, B.; Marcon, S.; Riccardi, G.; Tran, L.; Vikøren, T.; et al. Studies in bank voles reveal strain differences between chronic wasting disease prions from Norway and North America. Proc. Natl. Acad. Sci. USA 2020, 117, 31417-31426. [CrossRef]

67. Pritzkow, S.; Gorski, D.; Ramirez, F.; Telling, G.C.; Benestad, S.L.; Soto, C. North American and Norwegian Chronic Wasting Disease prions exhibit different potential for interspecies transmission and zoonotic risk. J. Infect. Dis. 2021. [CrossRef] [PubMed]

68. Angers, R.C.; Kang, H.E.; Napier, D.; Browning, S.; Seward, T.; Mathiason, C.; Balachandran, A.; McKenzie, D.; Castilla, J.; Soto, C.; et al. Prion strain mutation determined by prion protein conformational compatibility and primary structure. Science 2010, 328, 1154-1158. [CrossRef]

69. Hoover, C.E.; Davenport, K.A.; Henderson, D.M.; Denkers, N.D.; Mathiason, C.K.; Soto, C.; Zabel, M.D.; Hoover, E.A. Pathways of Prion Spread during Early Chronic Wasting Disease in Deer. J. Virol. 2017, 91, e00077-17. [CrossRef]

70. Johnson, C.J.; Herbst, A.; Duque-Velasquez, C.; Vanderloo, J.P.; Bochsler, P.; Chappell, R.; McKenzie, D. Prion protein polymorphisms affect chronic wasting disease progression. PLoS ONE 2011, 6, e17450. [CrossRef]

71. Marsh, R.F.; Kincaid, A.E.; Bessen, R.A.; Bartz, J.C. Interspecies transmission of chronic wasting disease prions to squirrel monkeys (Saimiri sciureus). J. Virol. 2005, 79, 13794-13796. [CrossRef]

72. Cassmann, E.D.; Frese, R.D.; Greenlee, J.J. Second passage of chronic wasting disease of mule deer to sheep by intracranial inoculation compared to classical scrapie. J. Vet. Diagn. Investig. 2021, 33, 711-720. [CrossRef]

73. Bartz, J.C.; Marsh, R.F.; McKenzie, D.I.; Aiken, J.M. The host range of chronic wasting disease is altered on passage in ferrets. Virology 1998, 251, 297-301. [CrossRef] [PubMed]

74. Moore, S.J.; West Greenlee, M.H.; Kondru, N.; Manne, S.; Smith, J.D.; Kunkle, R.A.; Kanthasamy, A.; Greenlee, J.J. Experimental Transmission of the Chronic Wasting Disease Agent to Swine after Oral or Intracranial Inoculation. J. Virol. 2017, 91, e00926-17. [CrossRef]

75. Zink, R.M. Genetic and evolutionary considerations of the Chronic Wasting Disease-Human species barrier. Infect. Genet. Evol. 2020, 84, 104484. [CrossRef]

76. Belay, E.D. Transmissible spongiform encephalopathies in humans. Annu. Rev. Microbiol. 1999, 53, 283-314. [CrossRef] [PubMed]

77. Brown, P.; Brandel, J.P.; Sato, T.; Nakamura, Y.; MacKenzie, J.; Will, R.G.; Ladogana, A.; Pocchiari, M.; Leschek, E.W.; Schonberger, L.B. Iatrogenic Creutzfeldt-Jakob disease, final assessment. Emerg. Infect. Dis. 2012, 18, 901-907. [CrossRef] [PubMed]

78. Ironside, J.W.; Ritchie, D.L.; Head, M.W. Prion diseases. Handb. Clin. Neurol. 2017, 145, 393-403. [CrossRef]

79. Ghani, A.C. The epidemiology of variant Creutzfeldt-Jakob disease in Europe. Microbes Infect. 2002, 4, 385-393. [CrossRef]

80. Will, R.G.; Zeidler, M.; Stewart, G.E.; Macleod, M.A.; Ironside, J.W.; Cousens, S.N.; Mackenzie, J.; Estibeiro, K.; Green, A.J.; Knight, R.S. Diagnosis of new variant Creutzfeldt-Jakob disease. Ann. Neurol. 2000, 47, 575-582. [CrossRef]

81. Kaski, D.; Mead, S.; Hyare, H.; Cooper, S.; Jampana, R.; Overell, J.; Knight, R.; Collinge, J.; Rudge, P. Variant CJD in an individual heterozygous for PRNP codon 129. Lancet 2009, 374, 2128. [CrossRef]

82. The National CJD Research \& Surveillance Unit (NCJDRSU). Available online: https://www.cjd.ed.ac.uk/ (accessed on 22 October 2021).

83. Goldgaber, D.; Goldfarb, L.G.; Brown, P.; Asher, D.M.; Brown, W.T.; Lin, S.; Teener, J.W.; Feinstone, S.M.; Rubenstein, R.; Kascsak, R.J. Mutations in familial Creutzfeldt-Jakob disease and Gerstmann-Sträussler-Scheinker's syndrome. Exp. Neurol. 1989, 106, 204-206. [CrossRef] 
84. Gambetti, P.; Kong, Q.; Zou, W.; Parchi, P.; Chen, S.G. Sporadic and familial CJD: Classification and characterisation. Br. Med. Bull. 2003, 66, 213-239. [CrossRef] [PubMed]

85. Parchi, P.; Castellani, R.; Capellari, S.; Ghetti, B.; Young, K.; Chen, S.G.; Farlow, M.; Dickson, D.W.; Sima, A.A.; Trojanowski, J.Q.; et al. Molecular basis of phenotypic variability in sporadic Creutzfeldt-Jakob disease. Ann. Neurol. 1996, 39, 767-778. [CrossRef]

86. Parchi, P.; Zou, W.; Wang, W.; Brown, P.; Capellari, S.; Ghetti, B.; Kopp, N.; Schulz-Schaeffer, W.J.; Kretzschmar, H.A.; Head, M.W.; et al. Genetic influence on the structural variations of the abnormal prion protein. Proc. Natl. Acad. Sci. USA 2000, 97, 10168-10172. [CrossRef]

87. Kobayashi, A.; Satoh, S.; Ironside, J.W.; Mohri, S.; Kitamoto, T. Type 1 and type 2 human PrPSc have different aggregation sizes in methionine homozygotes with sporadic, iatrogenic and variant Creutzfeldt-Jakob disease. J. Gen. Virol. 2005, 86, 237-240. [CrossRef]

88. Parchi, P.; Strammiello, R.; Notari, S.; Giese, A.; Langeveld, J.P.; Ladogana, A.; Zerr, I.; Roncaroli, F.; Cras, P.; Ghetti, B.; et al. Incidence and spectrum of sporadic Creutzfeldt-Jakob disease variants with mixed phenotype and co-occurrence of PrPSc types: An updated classification. Acta. Neuropathol. 2009, 118, 659-671. [CrossRef]

89. Parchi, P.; Giese, A.; Capellari, S.; Brown, P.; Schulz-Schaeffer, W.; Windl, O.; Zerr, I.; Budka, H.; Kopp, N.; Piccardo, P.; et al. Classification of sporadic Creutzfeldt-Jakob disease based on molecular and phenotypic analysis of 300 subjects. Ann. Neurol. 1999, 46, 224-233. [CrossRef]

90. Cali, I.; Castellani, R.; Yuan, J.; Al-Shekhlee, A.; Cohen, M.L.; Xiao, X.; Moleres, F.J.; Parchi, P.; Zou, W.Q.; Gambetti, P. Classification of sporadic Creutzfeldt-Jakob disease revisited. Brain 2006, 129, 2266-2277. [CrossRef] [PubMed]

91. Hill, A.F.; Joiner, S.; Wadsworth, J.D.; Sidle, K.C.; Bell, J.E.; Budka, H.; Ironside, J.W.; Collinge, J. Molecular classification of sporadic Creutzfeldt-Jakob disease. Brain 2003, 126, 1333-1346. [CrossRef]

92. Baiardi, S.; Capellari, S.; Ladogana, A.; Strumia, S.; Santangelo, M.; Pocchiari, M.; Parchi, P. Revisiting the Heidenhain Variant of Creutzfeldt-Jakob Disease: Evidence for Prion Type Variability Influencing Clinical Course and Laboratory Findings. J. Alzheimers Dis. 2016, 50, 465-476. [CrossRef]

93. Gajdusek, D.C. Unconventional viruses and the origin and disappearance of kuru. Science 1977, 197, 943-960. [CrossRef] [PubMed]

94. Medori, R.; Tritschler, H.J.; LeBlanc, A.; Villare, F.; Manetto, V.; Chen, H.Y.; Xue, R.; Leal, S.; Montagna, P.; Cortelli, P. Fatal familial insomnia, a prion disease with a mutation at codon 178 of the prion protein gene. N. Engl. J. Med. 1992, 326, 444-449. [CrossRef] [PubMed]

95. Piccardo, P.; Dlouhy, S.R.; Lievens, P.M.; Young, K.; Bird, T.D.; Nochlin, D.; Dickson, D.W.; Vinters, H.V.; Zimmerman, T.R.; Mackenzie, I.R.; et al. Phenotypic variability of Gerstmann-Sträussler-Scheinker disease is associated with prion protein heterogeneity. J. Neuropathol. Exp. Neurol. 1998, 57, 979-988. [CrossRef]

96. Kitagawa, Y.; Gotoh, F.; Koto, A.; Ebihara, S.; Okayasu, H.; Ishii, T.; Matsuyama, H. Creutzfeldt-Jakob disease: A case with extensive white matter degeneration and optic atrophy. J. Neurol. 1983, 229, 97-101. [CrossRef]

97. Lesser, R.L.; Albert, D.M.; Bobowick, A.R.; O'Brien, F.H. Creutzfeldt-Jakob disease and optic atrophy. Am. J. Ophthalmol. 1979, 87, 317-321. [CrossRef]

98. Yee, R.D.; Farlow, M.R.; Suzuki, D.A.; Betelak, K.F.; Ghetti, B. Abnormal eye movements in Gerstmann-Sträussler-Scheinker disease. Arch. Ophthalmol. 1992, 110, 68-74. [CrossRef]

99. Sugai, F.; Nakamori, M.; Nakatsuji, Y.; Abe, K.; Sakoda, S. A case of Gerstmann-Sträussler-Scheinker syndrome (P102L) accompanied by optic atrophy. Rinsho Shinkeigaku 2000, 40, 926-928. [PubMed]

100. West Greenlee, M.H.; Smith, J.D.; Platt, E.M.; Juarez, J.R.; Timms, L.L.; Greenlee, J.J. Changes in retinal function and morphology are early clinical signs of disease in cattle with bovine spongiform encephalopathy. PLoS ONE 2015, 10, e0119431.

101. Roth, N.M.; Saidha, S.; Zimmermann, H.; Brandt, A.U.; Isensee, J.; Benkhellouf-Rutkowska, A.; Dornauer, M.; Kühn, A.A.; Müller, T.; Calabresi, P.A.; et al. Photoreceptor layer thinning in idiopathic Parkinson's disease. Mov. Disord. 2014, 29, 1163-1170. [CrossRef] [PubMed]

102. Ngolab, J.; Honma, P.; Rissman, R.A. Reflections on the Utility of the Retina as a Biomarker for Alzheimer's Disease: A Literature Review. Neurol. Ther. 2019, 8, 57-72. [CrossRef]

103. Garcia-Martin, E.; Rodriguez-Mena, D.; Satue, M.; Almarcegui, C.; Dolz, I.; Alarcia, R.; Seral, M.; Polo, V.; Larrosa, J.M.; Pablo, L.E. Electrophysiology and optical coherence tomography to evaluate Parkinson disease severity. Investig. Ophthalmol. Vis. Sci. 2014, 55, 696-705. [CrossRef]

104. Formichella, C.R.; Abella, S.K.; Sims, S.M.; Cathcart, H.M.; Sappington, R.M. Astrocyte Reactivity: A Biomarker for Retinal Ganglion Cell Health in Retinal Neurodegeneration. J. Clin. Cell. Immunol. 2014, 5, 188. [CrossRef] [PubMed]

105. Cabrera DeBuc, D.; Somfai, G.M.; Arthur, E.; Kostic, M.; Oropesa, S.; Mendoza Santiesteban, C. Investigating Multimodal Diagnostic Eye Biomarkers of Cognitive Impairment by Measuring Vascular and Neurogenic Changes in the Retina. Front. Physiol. 2018, 9, 1721. [CrossRef]

106. Alonso, R.; Gonzalez-Moron, D.; Garcea, O. Optical coherence tomography as a biomarker of neurodegeneration in multiple sclerosis: A review. Mult. Scler. Relat. Disord. 2018, 22, 77-82. [CrossRef]

107. Snyder, P.J.; Alber, J.; Alt, C.; Bain, L.J.; Bouma, B.E.; Bouwman, F.H.; DeBuc, D.C.; Campbell, M.C.W.; Carrillo, M.C.; Chew, E.Y.; et al. Retinal imaging in Alzheimer's and neurodegenerative diseases. Alzheimers Dement. 2021, 17, 103-111. [CrossRef] [PubMed] 
108. Normando, E.M.; Davis, B.M.; De Groef, L.; Nizari, S.; Turner, L.A.; Ravindran, N.; Pahlitzsch, M.; Brenton, J.; Malaguarnera, G.; Guo, L.; et al. The retina as an early biomarke.er of neurodegeneration in a rotenone-induced model of Parkinson's disease: Evidence for a neuroprotective effect of rosiglitazone in the eye and brain. Acta. Neuropathol. Commun. 2016, 4, 86. [CrossRef]

109. Regnier, A.; Andreoletti, O.; Albaric, O.; Gruson, D.C.; Schelcher, F.; Toutain, P.L. Clinical, electroretinographic and histomorphometric evaluation of the retina in sheep with natural scrapie. BMC Vet. Res. 2011, 7, 25. [CrossRef]

110. Greenlee, J.J.; Smith, J.D.; West Greenlee, M.H.; Nicholson, E.M. Clinical and pathologic features of H-type Bovine Spongiform Encephalopathy associated with E211K prion protein polymorphism. PLoS ONE 2012, 7, e38678. [CrossRef] [PubMed]

111. Smith, J.D.; Greenlee, J.J. Detection of misfolded prion protein in retina samples of sheep and cattle by use of a commercially available enzyme immunoassay. Am. J. Vet. Res. 2014, 75, 268-272. [CrossRef]

112. Okada, H.; Iwamaru, Y.; Imamura, M.; Masujin, K.; Matsuura, Y.; Shimizu, Y.; Kasai, K.; Mohri, S.; Yokoyama, T.; Czub, S. Experimental $\mathrm{H}$-type bovine spongiform encephalopathy characterized by plaques and glial- and stellate-type prion protein deposits. Vet. Res. 2011, 42, 79. [CrossRef] [PubMed]

113. Greenlee, J.J.; Hamir, A.N.; West Greenlee, M.H. Abnormal prion accumulation associated with retinal pathology in experimentally inoculated scrapie-affected sheep. Vet. Pathol. 2006, 43, 733-739. [CrossRef]

114. Hamir, A.N.; Richt, J.A.; Kunkle, R.A.; Greenlee, J.J.; Bulgin, M.S.; Gregori, L.; Rohwer, R.G. Characterization of a US sheep scrapie isolate with short incubation time. Vet. Pathol. 2009, 46, 1205-1212. [CrossRef]

115. Moore, S.J.; Smith, J.D.; Greenlee, M.H.; Nicholson, E.M.; Richt, J.A.; Greenlee, J.J. Comparison of Two US Sheep Scrapie Isolates Supports Identification as Separate Strains. Vet. Pathol. 2016, 53, 1187-1196. [CrossRef]

116. Smith, J.D.; Greenlee, J.J.; Hamir, A.N.; West Greenlee, M.H. Retinal cell types are differentially affected in sheep with scrapie. J. Comp. Pathol. 2008, 138, 12-22. [CrossRef]

117. Chesebro, B.; Race, R.; Kercher, L. Scrapie pathogenesis in brain and retina: Effects of prion protein expression in neurons and astrocytes. J. Neurovirol. 2005, 11, 476-480. [CrossRef]

118. Hamir, A.N.; Kunkle, R.A.; Richt, J.A.; Greenlee, J.J.; Miller, J.M. Serial passage of sheep scrapie inoculum in Suffolk sheep. Vet. Pathol. 2009, 46, 39-44. [CrossRef] [PubMed]

119. Cassmann, E.D.; Moore, S.J.; Smith, J.D.; Greenlee, J.J. Sheep With the Homozygous Lysine-171 Prion Protein Genotype Are Resistant to Classical Scrapie After Experimental Oronasal Inoculation. Vet. Pathol. 2019, 56, 409-417. [CrossRef]

120. Jeffrey, M.; Martin, S.; Thomson, J.R.; Dingwall, W.S.; Begara-McGorum, I.; González, L. Onset and distribution of tissue prp accumulation in scrapie-affected suffolk sheep as demonstrated by sequential necropsies and tonsillar biopsies. J. Comp. Pathol. 2001, 125, 48-57. [CrossRef]

121. Spraker, T.R.; Zink, R.R.; Cummings, B.A.; Wild, M.A.; Miller, M.W.; O'Rourke, K.I. Comparison of histological lesions and immunohistochemical staining of proteinase-resistant prion protein in a naturally occurring spongiform encephalopathy of free-ranging mule deer (Odocoileus hemionus) with those of chronic wasting disease of captive mule deer. Vet. Pathol. 2002, 39, 110-119. [CrossRef] [PubMed]

122. Mammadova, N.; West Greenlee, M.H.; Moore, S.J.; Hwang, S.; Lehmkuhl, A.D.; Nicholson, E.M.; Greenlee, J.J. Evaluation of Antemortem Diagnostic Techniques in Goats Naturally Infected With Scrapie. Front. Vet. Sci. 2020, 7, 517862. [CrossRef]

123. Valdez, R.A.; Rock, M.J.; Anderson, A.K.; O’Rourke, K.I. Immunohistochemical detection and distribution of prion protein in a goat with natural scrapie. J. Vet. Diagn. Investig. 2003, 15, 157-162. [CrossRef]

124. Jeffrey, M.; Martin, S.; Chianini, F.; Eaton, S.; Dagleish, M.P.; González, L. Incidence of infection in Prnp ARR/ARR sheep following experimental inoculation with or natural exposure to classical scrapie. PLoS ONE 2014, 9, e91026. [CrossRef] [PubMed]

125. Spraker, T.R.; O’Rourke, K.I.; Gidlewski, T.; Powers, J.G.; Greenlee, J.J.; Wild, M.A. Detection of the abnormal isoform of the prion protein associated with chronic wasting disease in the optic pathways of the brain and retina of Rocky Mountain elk (Cervus elaphus nelsoni). Vet. Pathol. 2010, 47, 536-546. [CrossRef]

126. Ye, X. Visual pathology in animal prion diseases. Histol. Histopathol. 2009, 24, 1563-1577. [CrossRef]

127. Keane, D.P.; Barr, D.J.; Bochsler, P.N.; Hall, S.M.; Gidlewski, T.; O’Rourke, K.I.; Spraker, T.R.; Samuel, M.D. Chronic wasting disease in a Wisconsin white-tailed deer farm. J. Vet. Diagn. Investig. 2008, 20, 698-703. [CrossRef] [PubMed]

128. Hamir, A.N.; Richt, J.A.; Miller, J.M.; Kunkle, R.A.; Hall, S.M.; Nicholson, E.M.; O’Rourke, K.I.; Greenlee, J.J.; Williams, E.S. Experimental transmission of chronic wasting disease (CWD) of elk (Cervus elaphus nelsoni), white-tailed deer (Odocoileus virginianus), and mule deer (Odocoileus hemionus hemionus) to white-tailed deer by intracerebral route. Vet. Pathol. 2008, 45, 297-306. [CrossRef] [PubMed]

129. Otero, A.; Duque Velásquez, C.; Johnson, C.; Herbst, A.; Bolea, R.; Badiola, J.J.; Aiken, J.; McKenzie, D. Prion protein polymorphisms associated with reduced CWD susceptibility limit peripheral PrP CWD deposition in orally infected white-tailed deer. BMC Vet. Res. 2019, 15, 50. [CrossRef] [PubMed]

130. Moore, S.J.; Vrentas, C.E.; Hwang, S.; West Greenlee, M.H.; Nicholson, E.M.; Greenlee, J.J. Pathologic and biochemical characterization of PrPSc from elk with PRNP polymorphisms at codon 132 after experimental infection with the chronic wasting disease agent. BMC Vet. Res. 2018, 14, 80. [CrossRef] [PubMed]

131. Mitchell, G.B.; Sigurdson, C.J.; O’Rourke, K.I.; Algire, J.; Harrington, N.P.; Walther, I.; Spraker, T.R.; Balachandran, A. Experimental oral transmission of chronic wasting disease to reindeer (Rangifer tarandus tarandus). PLoS ONE 2012, 7, e39055. [CrossRef]

132. Moore, S.J.; Kunkle, R.; Greenlee, M.H.; Nicholson, E.; Richt, J.; Hamir, A.; Waters, W.R.; Greenlee, J. Horizontal Transmission of Chronic Wasting Disease in Reindeer. Emerg. Infect. Dis. 2016, 22, 2142-2145. [CrossRef] 
133. Mammadova, N.; Cassmann, E.; Greenlee, J.J. Successful transmission of the chronic wasting disease (CWD) agent to white-tailed deer by intravenous blood transfusion. Res. Vet. Sci. 2020, 133, 304-306. [CrossRef]

134. Head, M.W.; Peden, A.H.; Yull, H.M.; Ritchie, D.L.; Bonshek, R.E.; Tullo, A.B.; Ironside, J.W. Abnormal prion protein in the retina of the most commonly occurring subtype of sporadic Creutzfeldt-Jakob disease. Br. J. Ophthalmol. 2005, 89, 1131-1133. [CrossRef]

135. Head, M.W.; Northcott, V.; Rennison, K.; Ritchie, D.; McCardle, L.; Bunn, T.J.; McLennan, N.F.; Ironside, J.W.; Tullo, A.B.; Bonshek, R.E. Prion protein accumulation in eyes of patients with sporadic and variant Creutzfeldt-Jakob disease. Investig. Ophthalmol. Vis. Sci. 2003, 44, 342-346. [CrossRef] [PubMed]

136. Takao, M.; Kimura, H.; Kitamoto, T.; Mihara, B. PrP res deposition in the retina is a common finding of sporadic, familial and iatrogenic Creutzfeldt-Jakob diseases (CJD). Acta. Neuropathol. Commun. 2018, 6, 78. [CrossRef]

137. Wadsworth, J.D.; Joiner, S.; Hill, A.F.; Campbell, T.A.; Desbruslais, M.; Luthert, P.J.; Collinge, J. Tissue distribution of protease resistant prion protein in variant Creutzfeldt-Jakob disease using a highly sensitive immunoblotting assay. Lancet 2001, 358, 171-180. [CrossRef]

138. Baden, T.; Berens, P.; Franke, K.; Román Rosón, M.; Bethge, M.; Euler, T. The functional diversity of retinal ganglion cells in the mouse. Nature 2016, 529, 345-350. [CrossRef]

139. West Greenlee, M.H.; Lind, M.; Kokemuller, R.; Mammadova, N.; Kondru, N.; Manne, S.; Smith, J.; Kanthasamy, A.; Greenlee, J. Temporal Resolution of Misfolded Prion Protein Transport, Accumulation, Glial Activation, and Neuronal Death in the Retinas of Mice Inoculated with Scrapie. Am. J. Pathol. 2016, 186, 2302-2309. [CrossRef]

140. Ayers, J.I.; Schutt, C.R.; Shikiya, R.A.; Aguzzi, A.; Kincaid, A.E.; Bartz, J.C. The Strain-Encoded Relationship between PrPSc Replication, Stability and Processing in Neurons is Predictive of the Incubation Period of Disease. PLoS Pathog. 2011, 7, e1001317. [CrossRef] [PubMed]

141. Orru, C.D.; Soldau, K.; Cordano, C.; Llibre-Guerra, J.; Green, A.J.; Sanchez, H.; Groveman, B.R.; Edland, S.D.; Safar, J.G.; Lin, J.H.; et al. Prion Seeds Distribute throughout the Eyes of Sporadic Creutzfeldt-Jakob Disease Patients. mBio 2018, 9, e02095-18. [CrossRef]

142. Hamir, A.N.; Kunkle, R.A.; Miller, J.M.; Richt, J.A. Second passage of sheep scrapie and transmissible mink encephalopathy (TME) agents in raccoons (Procyon lotor). Vet. Pathol. 2005, 42, 844-851. [CrossRef]

143. Collinge, J.; Whittington, M.A.; Sidle, K.C.; Smith, C.J.; Palmer, M.S.; Clarke, A.R.; Jefferys, J.G. Prion protein is necessary for normal synaptic function. Nature 1994, 370, 295-297. [CrossRef] [PubMed]

144. Smith, J.D.; Greenlee, J.J.; Hamir, A.N.; Richt, J.A.; Greenlee, M.H. Retinal function and morphology are altered in cattle infected with the prion disease transmissible mink encephalopathy. Vet. Pathol. 2009, 46, 810-818. [CrossRef]

145. de Seze, J.; Hache, J.C.; Vermersch, P.; Arndt, C.F.; Maurage, C.A.; Pasquier, F.; Laplanche, J.L.; Ruchoux, M.M.; Leys, D.; Destée, A.; et al. Creutzfeldt-Jakob disease: Neurophysiologic visual impairments. Neurology 1998, 51, 962-967. [CrossRef]

146. Ishikawa, A.; Tanikawa, A.; Shimada, Y.; Mutoh, T.; Yamamoto, H.; Horiguchi, M. Electroretinograms in three cases of CreutzfeldtJakob disease with visual disturbances. Jpn. J. Ophthalmol. 2009, 53, 31-34. [CrossRef] [PubMed]

147. Casalone, C.; Zanusso, G.; Acutis, P.; Ferrari, S.; Capucci, L.; Tagliavini, F.; Monaco, S.; Caramelli, M. Identification of a second bovine amyloidotic spongiform encephalopathy: Molecular similarities with sporadic Creutzfeldt-Jakob disease. Proc. Natl. Acad. Sci. USA 2004, 101, 3065-3070. [CrossRef] [PubMed]

148. Vrentas, C.E.; Greenlee, J.J.; Baron, T.; Caramelli, M.; Czub, S.; Nicholson, E.M. Stability properties of PrP(Sc) from cattle with experimental transmissible spongiform encephalopathies: Use of a rapid whole homogenate, protease-free assay. BMC Vet. Res. 2013, 9, 167. [CrossRef]

149. Mammadova, N.; Cassmann, E.; Greenlee, J.J. Efficient transmission of classical scrapie agent x124 by intralingual route to genetically susceptible sheep with a low dose inoculum. Res. Vet. Sci. 2020, 132, 217-220. [CrossRef] [PubMed]

150. Hardt, M.; Baron, T.; Groschup, M.H. A comparative study of immunohistochemical methods for detecting abnormal prion protein with monoclonal and polyclonal antibodies. J. Comp. Pathol. 2000, 122, 43-53. [CrossRef]

151. Stack, M.J.; Chaplin, M.J.; Clark, J. Differentiation of prion protein glycoforms from naturally occurring sheep scrapie, sheeppassaged scrapie strains (CH1641 and SSBP1), bovine spongiform encephalopathy (BSE) cases and Romney and Cheviot breed sheep experimentally inoculated with BSE using two monoclonal antibodies. Acta. Neuropathol. 2002, 104, 279-286. [CrossRef]

152. Greenlee, J.J.; Smith, J.D.; Kunkle, R.A. White-tailed deer are susceptible to the agent of sheep scrapie by intracerebral inoculation. Vet. Res. 2011, 42, 107. [CrossRef] [PubMed]

153. Bugiani, O.; Giaccone, G.; Piccardo, P.; Morbin, M.; Tagliavini, F.; Ghetti, B. Neuropathology of Gerstmann-Sträussler-Scheinker disease. Microsc. Res. Tech. 2000, 50, 10-15. [CrossRef]

154. Long, L.; Cai, X.; Shu, Y.; Lu, Z. A family with hereditary cerebellar ataxia finally confirmed as Gerstmann-Straussler-Scheinker syndrome with P102L mutation in PRNP gene. Neurosci (Riyadh) 2017, 22, 138-142. [CrossRef]

155. Hainfellner, J.A.; Liberski, P.P.; Guiroy, D.C.; Cervénaková, L.; Brown, P.; Gajdusek, D.C.; Budka, H. Pathology and immunocytochemistry of a kuru brain. Brain. Pathol. 1997, 7, 547-553. [CrossRef]

156. Scrimgeour, E.M.; Masters, C.L.; Alpers, M.P.; Kaven, J.; Gajusek, D.C. A clinico-pathological study of a case of kuru. J. Neurol. Sci. 1983, 59, 265-275. [CrossRef]

157. Liberski, P.P.; Sikorska, B.; Lindenbaum, S.; Goldfarb, L.G.; McLean, C.; Hainfellner, J.A.; Brown, P. Kuru: Genes, cannibals and neuropathology. J. Neuropathol. Exp. Neurol. 2012, 71, 92-103. [CrossRef] 
158. Brandner, S.; Whitfield, J.; Boone, K.; Puwa, A.; O’Malley, C.; Linehan, J.M.; Joiner, S.; Scaravilli, F.; Calder, I.; Alpers, M.P.; et al. Central and peripheral pathology of kuru: Pathological analysis of a recent case and comparison with other forms of human prion disease. Philos. Trans. R. Soc. Lond. B. Biol. Sci. 2008, 363, 3755-3763. [CrossRef]

159. Konold, T.; Bone, G.E.; Clifford, D.; Chaplin, M.J.; Cawthraw, S.; Stack, M.J.; Simmons, M.M. Experimental H-type and L-type bovine spongiform encephalopathy in cattle: Observation of two clinical syndromes and diagnostic challenges. BMC Vet. Res. 2012, 8, 22. [CrossRef] [PubMed]

160. Polak, M.P.; Zmudzinski, J.F. Distribution of a pathological form of prion protein in the brainstem and cerebellum in classical and atypical cases of bovine spongiform encephalopathy. Vet. J. 2012, 191, 128-130. [CrossRef] [PubMed]

161. Moore, S.J.; Simmons, M.; Chaplin, M.; Spiropoulos, J. Neuroanatomical distribution of abnormal prion protein in naturally occurring atypical scrapie cases in Great Britain. Acta. Neuropathol. 2008, 116, 547-559. [CrossRef] [PubMed]

162. Guiroy, D.C.; Williams, E.S.; Yanagihara, R.; Gajdusek, D.C. Immunolocalization of scrapie amyloid (PrP27-30) in chronic wasting disease of Rocky Mountain elk and hybrids of captive mule deer and white-tailed deer. Neurosci. Lett. 1991, 126, 195-198. [CrossRef]

163. Yang, Q.; Hashizume, Y.; Yoshida, M.; Wang, Y. Neuropathological study of cerebellar degeneration in prion disease. Neuropathology 1999, 19, 33-39. [CrossRef]

164. Konold, T.; Bone, G.E.; Phelan, L.J.; Simmons, M.M.; González, L.; Sisó, S.; Goldmann, W.; Cawthraw, S.; Hawkins, S.A. Monitoring of clinical signs in goats with transmissible spongiform encephalopathies. BMC Vet. Res. 2010, 6, 13. [CrossRef]

165. Budka, H.; Aguzzi, A.; Brown, P.; Brucher, J.M.; Bugiani, O.; Gullotta, F.; Haltia, M.; Hauw, J.J.; Ironside, J.W.; Jellinger, K. Neuropathological diagnostic criteria for Creutzfeldt-Jakob disease (CJD) and other human spongiform encephalopathies (prion diseases). Brain. Pathol. 1995, 5, 459-466. [CrossRef]

166. Narang, H.K. A critical review of atypical cerebellum-type Creutzfeldt-Jakob disease: Its relationship to "new variant" CJD and bovine spongiform encephalopathy. Exp. Biol. Med. 2001, 226, 629-639. [CrossRef]

167. Okada, H.; Iwamaru, Y.; Imamura, M.; Masujin, K.; Matsuura, Y.; Shimizu, Y.; Kasai, K.; Takata, M.; Fukuda, S.; Nikaido, S.; et al. Neuroanatomical distribution of disease-associated prion protein in cases of bovine spongiform encephalopathy detected by fallen stock surveillance in Japan. J. Vet. Med. Sci. 2011, 73, 1465-1471. [CrossRef] [PubMed]

168. Sisó, S.; Ordóñez, M.; Cordón, I.; Vidal, E.; Pumarola, M. Distribution of PrP(res) in the brains of BSE-affected cows detected by active surveillance in Catalonia, Spain. Vet. Rec. 2004, 155, 524-525. [CrossRef]

169. Vidal, E.; Márquez, M.; Tortosa, R.; Costa, C.; Serafín, A.; Pumarola, M. Immunohistochemical approach to the pathogenesis of bovine spongiform encephalopathy in its early stages. J. Virol. Methods 2006, 134, 15-29. [CrossRef] [PubMed]

170. Okada, H.; Iwamaru, Y.; Kakizaki, M.; Masujin, K.; Imamura, M.; Fukuda, S.; Matsuura, Y.; Shimizu, Y.; Kasai, K.; Mohri, S.; et al. Properties of L-type bovine spongiform encephalopathy in intraspecies passages. Vet. Pathol. 2012, 49, 819-823. [CrossRef]

171. Nentwig, A.; Oevermann, A.; Heim, D.; Botteron, C.; Zellweger, K.; Drögemüller, C.; Zurbriggen, A.; Seuberlich, T. Diversity in neuroanatomical distribution of abnormal prion protein in atypical scrapie. PLoS Pathog. 2007, 3, e82. [CrossRef] [PubMed]

172. Kittelberger, R.; Chaplin, M.J.; Simmons, M.M.; Ramirez-Villaescusa, A.; McIntyre, L.; MacDiarmid, S.C.; Hannah, M.J.; Jenner, J.; Bueno, R.; Bayliss, D.; et al. Atypical scrapie/Nor98 in a sheep from New Zealand. J. Vet. Diagn. Investig. 2010, 22, 863-875. [CrossRef]

173. Okada, H.; Miyazawa, K.; Imamura, M.; Iwamaru, Y.; Masujin, K.; Matsuura, Y.; Yokoyama, T. Transmission of atypical scrapie to homozygous ARQ sheep. J. Vet. Med. Sci. 2016, 78, 1619-1624. [CrossRef]

174. Guiroy, D.C.; Williams, E.S.; Yanagihara, R.; Gajdusek, D.C. Topographic distribution of scrapie amyloid-immunoreactive plaques in chronic wasting disease in captive mule deer (Odocoileus hemionus hemionus). Acta Neuropathol. 1991, 81, 475-478. [CrossRef]

175. Armstrong, R.A.; Ironside, J.W.; Lantos, P.L.; Cairns, N.J. A quantitative study of the pathological changes in the cerebellum in 15 cases of variant Creutzfeldt-Jakob disease (vCJD). Neuropathol. Appl. Neurobiol. 2009, 35, 36-45. [CrossRef]

176. Schulz-Schaeffer, W.J.; Giese, A.; Windl, O.; Kretzschmar, H.A. Polymorphism at codon 129 of the prion protein gene determines cerebellar pathology in Creutzfeldt-Jakob disease. Clin. Neuropathol. 1996, 15, 353-357.

177. Shijo, M.; Honda, H.; Koyama, S.; Ishitsuka, K.; Maeda, K.; Kuroda, J.; Tanii, M.; Kitazono, T.; Iwaki, T. Dura mater graft-associated Creutzfeldt-Jakob disease with 30-year incubation period. Neuropathology 2017, 37, 275-281. [CrossRef]

178. Armstrong, R.A.; Cairns, N.J. Spatial patterns of the pathological changes in the cerebellar cortex in sporadic Creutzfeldt-Jakob disease (sCJD). Folia Neuropathol. 2003, 41, 183-189.

179. Ferrer, I.; Puig, B.; Blanco, R.; Martí, E. Prion protein deposition and abnormal synaptic protein expression in the cerebellum in Creutzfeldt-Jakob disease. Neuroscience 2000, 97, 715-726. [CrossRef]

180. Cervenáková, L.; Goldfarb, L.G.; Garruto, R.; Lee, H.S.; Gajdusek, D.C.; Brown, P. Phenotype-genotype studies in kuru: Implications for new variant Creutzfeldt-Jakob disease. Proc. Natl. Acad. Sci. USA 1998, 95, 13239-13241. [CrossRef] [PubMed]

181. van Keulen, L.J.; Schreuder, B.E.; Vromans, M.E.; Langeveld, J.P.; Smits, M.A. Scrapie-associated prion protein in the gastrointestinal tract of sheep with natural scrapie. J. Comp. Pathol. 1999, 121, 55-63. [CrossRef] [PubMed]

182. Balkema-Buschmann, A.; Priemer, G.; Ulrich, R.; Strobelt, R.; Hills, B.; Groschup, M.H. Deciphering the BSE-type specific cell and tissue tropisms of atypical (H and L) and classical BSE. Prion 2019, 13, 160-172. [CrossRef]

183. Kaatz, M.; Fast, C.; Ziegler, U.; Balkema-Buschmann, A.; Hammerschmidt, B.; Keller, M.; Oelschlegel, A.; McIntyre, L.; Groschup, M.H. Spread of classic BSE prions from the gut via the peripheral nervous system to the brain. Am. J. Pathol. 2012, 181, 515-524. [CrossRef] 
184. González, L.; Pitarch, J.L.; Martin, S.; Thurston, L.; Simmons, H.; Acín, C.; Jeffrey, M. Influence of polymorphisms in the prion protein gene on the pathogenesis and neuropathological phenotype of sheep scrapie after oral infection. J. Comp. Pathol. 2014, 150, 57-70. [CrossRef]

185. Terry, L.A.; Marsh, S.; Ryder, S.J.; Hawkins, S.A.; Wells, G.A.; Spencer, Y.I. Detection of disease-specific PrP in the distal ileum of cattle exposed orally to the agent of bovine spongiform encephalopathy. Vet. Rec. 2003, 152, 387-392. [CrossRef] [PubMed]

186. Hoffmann, C.; Eiden, M.; Kaatz, M.; Keller, M.; Ziegler, U.; Rogers, R.; Hills, B.; Balkema-Buschmann, A.; van Keulen, L.; Jacobs, J.G.; et al. BSE infectivity in jejunum, ileum and ileocaecal junction of incubating cattle. Vet. Res. 2011, 42, 21. [CrossRef] [PubMed]

187. Franz, M.; Eiden, M.; Balkema-Buschmann, A.; Greenlee, J.; Schatzl, H.; Fast, C.; Richt, J.; Hildebrandt, J.P.; Groschup, M.H. Detection of $\operatorname{PrP}(\mathrm{Sc})$ in peripheral tissues of clinically affected cattle after oral challenge with bovine spongiform encephalopathy. J. Gen. Virol. 2012, 93, 2740-2748. [CrossRef]

188. Balkema-Buschmann, A.; Fast, C.; Kaatz, M.; Eiden, M.; Ziegler, U.; McIntyre, L.; Keller, M.; Hills, B.; Groschup, M.H. Pathogenesis of classical and atypical BSE in cattle. Prev. Vet. Med. 2011, 102, 112-117. [CrossRef]

189. van Keulen, L.J.; Vromans, M.E.; van Zijderveld, F.G. Early and late pathogenesis of natural scrapie infection in sheep. APMIS 2002, 110, 23-32. [CrossRef] [PubMed]

190. Andréoletti, O.; Berthon, P.; Marc, D.; Sarradin, P.; Grosclaude, J.; van Keulen, L.; Schelcher, F.; Elsen, J.M.; Lantier, F. Early accumulation of $\operatorname{PrP}(\mathrm{Sc})$ in gut-associated lymphoid and nervous tissues of susceptible sheep from a Romanov flock with natural scrapie. J. Gen. Virol. 2000, 81, 3115-3126. [CrossRef]

191. van Keulen, L.J.; Schreuder, B.E.; Vromans, M.E.; Langeveld, J.P.; Smits, M.A. Pathogenesis of natural scrapie in sheep. Arch. Virol. Suppl. 2000, 16, 57-71. [CrossRef]

192. Heggebø, R.; González, L.; Press, C.M.; Gunnes, G.; Espenes, A.; Jeffrey, M. Disease-associated PrP in the enteric nervous system of scrapie-affected Suffolk sheep. J. Gen. Virol. 2003, 84, 1327-1338. [CrossRef]

193. Marruchella, G.; Ligios, C.; Albanese, V.; Cancedda, M.G.; Madau, L.; Lalatta-Costerbosa, G.; Mazzoni, M.; Clavenzani, P.; Chiocchetti, R.; Sarli, G.; et al. Enteroglial and neuronal involvement without apparent neuron loss in ileal enteric nervous system plexuses from scrapie-affected sheep. J. Gen. Virol. 2007, 88, 2899-2904. [CrossRef]

194. Jeffrey, M.; González, L.; Espenes, A.; Press, C.M.; Martin, S.; Chaplin, M.; Davis, L.; Landsverk, T.; MacAldowie, C.; Eaton, S.; et al. Transportation of prion protein across the intestinal mucosa of scrapie-susceptible and scrapie-resistant sheep. J. Pathol. 2006, 209, 4-14. [CrossRef]

195. Simmons, M.M.; Moore, S.J.; Konold, T.; Thurston, L.; Terry, L.A.; Thorne, L.; Lockey, R.; Vickery, C.; Hawkins, S.A.; Chaplin, M.J.; et al. Experimental oral transmission of atypical scrapie to sheep. Emerg. Infect. Dis. 2011, 17, 848-854. [CrossRef]

196. Andréoletti, O.; Orge, L.; Benestad, S.L.; Beringue, V.; Litaise, C.; Simon, S.; Le Dur, A.; Laude, H.; Simmons, H.; Lugan, S.; et al. Atypical/Nor98 scrapie infectivity in sheep peripheral tissues. PLoS Pathog. 2011, 7, e1001285. [CrossRef]

197. Spraker, T.R.; VerCauteren, K.C.; Gidlewski, T.; Schneider, D.A.; Munger, R.; Balachandran, A.; O'Rourke, K.I. Antemortem detection of PrPCWD in preclinical, ranch-raised Rocky Mountain elk (Cervus elaphus nelsoni) by biopsy of the rectal mucosa. J. Vet. Diagn. Investig. 2009, 21, 15-24. [CrossRef] [PubMed]

198. Sigurdson, C.J.; Spraker, T.R.; Miller, M.W.; Oesch, B.; Hoover, E.A. $\operatorname{PrP}(C W D)$ in the myenteric plexus, vagosympathetic trunk and endocrine glands of deer with chronic wasting disease. J. Gen. Virol. 2001, 82, 2327-2334. [CrossRef]

199. Shmakov, A.N.; McLennan, N.F.; McBride, P.; Farquhar, C.F.; Bode, J.; Rennison, K.A.; Ghosh, S. Cellular prion protein is expressed in the human enteric nervous system. Nat. Med. 2000, 6, 840-841. [CrossRef]

200. Hainfellner, J.A.; Budka, H. Disease associated prion protein may deposit in the peripheral nervous system in human transmissible spongiform encephalopathies. Acta. Neuropathol. 1999, 98, 458-460. [CrossRef]

201. Gill, O.N.; Spencer, Y.; Richard-Loendt, A.; Kelly, C.; Dabaghian, R.; Boyes, L.; Linehan, J.; Simmons, M.; Webb, P.; Bellerby, P.; et al. Prevalent abnormal prion protein in human appendixes after bovine spongiform encephalopathy epizootic: Large scale survey. BMJ 2013, 347, f5675. [CrossRef] [PubMed]

202. Hanani, M. Multiple myenteric networks in the human appendix. Auton. Neurosci. 2004, 110, 49-54. [CrossRef] [PubMed] 